\title{
Threshold values and management options for nutrients in a catchment of a temperate estuary with poor ecological status
}

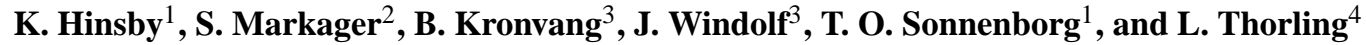 \\ ${ }^{1}$ Dept. Hydrology, Geological Survey of Denmark and Greenland, Copenhagen, Denmark \\ ${ }^{2}$ Dept. Bioscience, Aarhus University, Roskilde, Denmark \\ ${ }^{3}$ Dept. Bioscience, Aarhus University, Silkeborg, Denmark \\ ${ }^{4}$ Dept. Groundwater and Quaternary Geology Mapping, Geological Survey of Denmark and Greenland, Aarhus, Denmark
}

Correspondence to: K. Hinsby (khi@geus.dk)

Received: 2 February 2012 - Published in Hydrol. Earth Syst. Sci. Discuss.: 20 February 2012

Revised: 4 July 2012 - Accepted: 6 July 2012 - Published: 13 August 2012

\begin{abstract}
Intensive farming has severe impacts on the chemical status of groundwater and streams and consequently on the ecological status of dependent ecosystems. Eutrophication is a widespread problem in lakes and marine waters. Common problems are hypoxia, algal blooms, fish kills, and loss of water clarity, underwater vegetation, biodiversity and recreational value. In this paper we evaluate the nitrogen $(\mathrm{N})$ and phosphorus $(\mathrm{P})$ concentrations of groundwater and surface water in a coastal catchment, the loadings and sources of $\mathrm{N}$ and $\mathrm{P}$, and their effect on the ecological status of an estuary. We calculate the necessary reductions in $\mathrm{N}$ and $\mathrm{P}$ loadings to the estuary for obtaining a good ecological status, which we define based on the number of days with $\mathrm{N}$ and $\mathrm{P}$ limitation, and the corresponding stream and groundwater threshold values assuming two different management options. The calculations are performed by the combined use of empirical models and a physically based 3-D integrated hydrological model of the whole catchment. The assessment of the ecological status indicates that the $\mathrm{N}$ and $\mathrm{P}$ loads to the investigated estuary should be reduced to levels corresponding to 52 and $56 \%$ of the current loads, respectively, to restore good ecological status. Model estimates show that threshold total $\mathrm{N}$ (TN) concentrations should be in the range of 2.9 to $3.1 \mathrm{mg} \mathrm{l}^{-1}$ in inlet freshwater (streams) to Horsens estuary and 6.0 to $9.3 \mathrm{mg} \mathrm{l}^{-1}$ in shallow aerobic groundwater ( 27-41 $\mathrm{mg} \mathrm{l}^{-1}$ of nitrate), depending on the management measures implemented in the catchment. The situation for total P (TP) is more complex, but data indicate that groundwater threshold values are not needed. The stream threshold value for TP to Horsens estuary for the selected management
\end{abstract}

options is $0.084 \mathrm{mg} \mathrm{l}^{-1}$. Regional climate models project increasing winter precipitation and runoff in the investigated region resulting in increasing runoff and nutrient loads to the Horsens estuary and many other coastal waters if present land use and farming practices continue. Hence, lower threshold values are required in many coastal catchments in the future to ensure good status of water bodies and ecosystems.

\section{Introduction}

Nutrient emissions from anthropogenic sources have severe impacts on the environment and cause significant problems with the chemical status of water resources and the ecological status of terrestrial, freshwater, and marine ecosystems in Denmark and the Baltic Sea region (Conley et al., 2000; HELCOM, 2007), as well as globally (Vitousek et al., 1997; Tilman et al., 2001; Galloway et al., 2004; Diaz and Rosenberg, 2008; Conley et al., 2009; Rockstrøm et al., 2009). Rockstrøm et al. (2009) identify the human impact on the biogeochemical cycle of nitrogen as one of the currently most severe environmental problems globally and recommend that the human fixation of nitrogen and emissions of reactive nitrogen species are reduced to $25 \%$ of the present levels. Hence, there is a strong and increasing need to regulate and reduce nutrient loadings, particularly in areas with intensive farming, in order to protect water resources and ecosystems (Tilman et al., 2001; Rockstrøm et al., 2009).

The European Groundwater Directive (EU, 2006) stipulates that the European Union (EU) member states have to 
derive groundwater threshold values for all relevant contaminants in all groundwater bodies that may put associated ecosystems at risk. These risks include harmful algal blooms, hypoxia, and loss of biodiversity and underwater vegetation in aquatic ecosystems (Cloern, 2001; Conley et al., 2002). Groundwater threshold values are concentrations which should not be exceeded in order to assure good chemical and ecological status of groundwater associated or dependent ecosystems (Hinsby et al., 2008). If the threshold value for a given pollutant is exceeded, the groundwater body is classified as having poor chemical status according to EU directives (EU, 2000, 2006). Presently, the EU directives do not require a similar derivation of stream threshold values based on the ecological status of their marine recipient. However, we recommend that stream and groundwater threshold values be derived together, as stream threshold values can be calculated directly from estimated maximum nutrient loads to lakes and marine areas when the relative nutrient loads to these recipients directly from groundwater and streams have been estimated. Groundwater threshold values can then be estimated based on the stream threshold values from the groundwater contributions to stream and estuary nutrient loads as estimated by monitoring and modeling data. It should be noted that it may be necessary to set stricter nutrient threshold values for streams (e.g. Camargo and Alonso, 2006) or even for groundwater in some cases (Griebler et al., 2010). In this paper, however, we solely derive groundwater and stream threshold values based on the ecological status of the Horsens estuary.

An integrated assessment of threshold values for groundwater based on targets for protection of associated or dependent ecosystems is an interdisciplinary challenge that needs contributions from disciplines like marine and freshwater ecology, hydrology, hydrogeology, and hydrochemistry, as well as data for all water bodies in the investigated hydrological system. To the authors' knowledge, this is the first interdisciplinary study that estimates groundwater threshold values based on targets for the ecological status of a marine ecosystem. In this paper we (1) calculate total land based nitrogen and phosphorus loads, (2) estimate maximum acceptable nitrogen and phosphorus loads to the estuary in order to ensure a good ecological status of the estuary, (3) derive the equivalent nitrogen and phosphorus groundwater and stream threshold values for protection of the estuary, and (4) assess the present chemical status of groundwater in the catchment to Horsens estuary relative to the derived groundwater threshold values.

Our aim is to provide and demonstrate a methodology for derivation of threshold values and integrated assessment of nutrient transport across hydrological systems, from groundwater to estuaries, using Horsens estuary and its catchment as an example. Further, our aim is to contribute to the knowledge base, system understanding and framework for future assessments of the impacts of projected climate change on the evolution of the quantitative, chemical and ecological status of coastal catchments.

\section{Study area}

\subsection{The catchment}

The area of investigation is a $518 \mathrm{~km}^{2}$ Danish coastal catchment including the small islands in the estuary (Fig. 1). The catchment consists of two major gauged sub-catchments with gauging stations just upstream of the two major lakes in the area, discharging about $70 \%$ of the freshwater from the total catchment through the two lakes into the inner western part of the estuary. A number of smaller ungauged subcatchments discharge to the estuary via a number of small streams on both sides of the estuary (Fig. 1). The dominant land use is agriculture $(76 \%)$. The remaining areas are forested $(10 \%)$, or lakes, wetlands and meadows $(5 \%)$ (BLST, 2010). The population in the area is about 110000 (136 inhabitants per $\mathrm{km}^{2}$ ), of which $73 \%$ lives in municipalities with sewer systems. The animal production is dominated by pigs $(69 \%)$ and cows $(26 \%)$, and the area currently contains 0.79 livestock animal units (AU) per hectare agricultural soil (BLST, 2010).

The geology and topography of the area was developed by glacial processes during the last glaciation (Weichselian/Wisconsinian). The deposits are mainly clay tills and outwash sands constituting the main aquitards and aquifers, although some glaciolacustrine clay layers also exist. A conceptual model of the geological and hydrological setting in the catchment with indication of the type of available data, nutrient sources, and transport is shown in Fig. 2.

There are five lakes located in the catchment (total surface area: $2.43 \mathrm{~km}^{2}$ ), around 1700 ponds (total surface area: $2.21 \mathrm{~km}^{2}$ ), and the catchment is drained by $595 \mathrm{~km}$ of streams, of which $78 \%$ are less than $2 \mathrm{~m}$ wide. The mean precipitation for the agro-hydrological years (AprilMarch) 2000 to 2005, the period we model in this study, was $695 \mathrm{~mm} \mathrm{yr}^{-1}$, and the corresponding total discharge from the catchment to the estuary was $299 \mathrm{~mm} \mathrm{yr}^{-1}$.

\subsection{The estuary}

The Horsens estuary is a shallow estuary with a mean depth of $2.9 \mathrm{~m}$ and a surface area of $77.5 \mathrm{~km}^{2}$ (Stedmon et al., 2006; Markager et al., 2011). Tidal range is low and mixing is mainly wind driven (Gustafsson and Bendtsen, 2007). The estuary is connected to the Belt Sea and the Baltic Sea transitions zone through a deep (16 $\mathrm{m})$ channel and is generally well mixed with salinities from 12 to $26 \%$, which is comparable to the salinity in the Belt Sea. Despite the well mixed conditions, results from a 3-D ecological modeling study (Timmermann et al., 2010) showed that the ecological conditions in the estuary are mainly governed by local nutrient inputs with the nutrient concentrations in the adjacent 


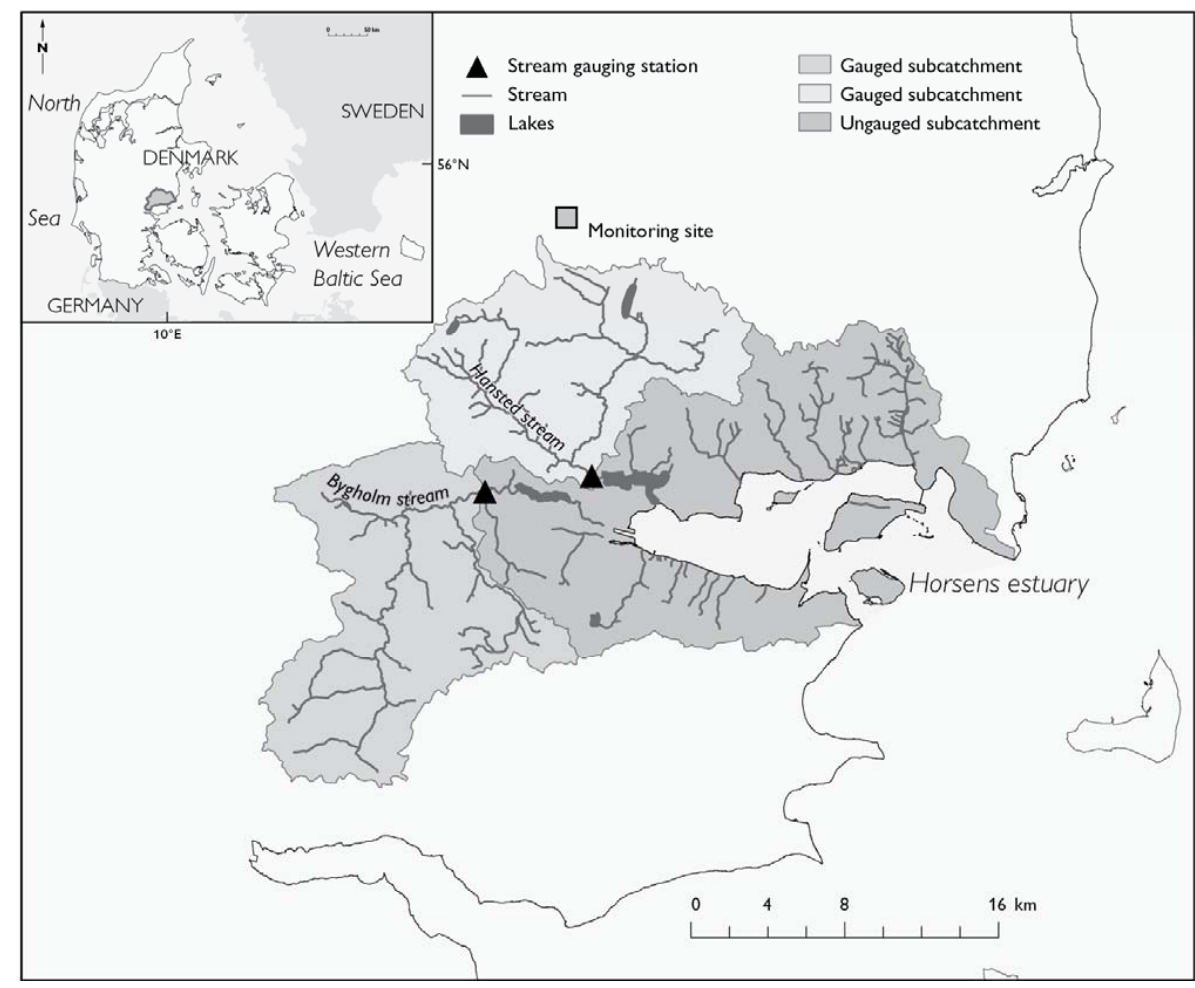

Fig. 1. Location and delineation of the investigated estuary and catchment, including stream gauging stations (triangles) and national monitoring site below farm land (square).

sea only playing a minor role. The nutrient concentrations in the estuary are typical for Danish estuaries and similar to estuaries in the US such as the Patuxent river estuary and Chesapeake Bay (Boynton and Kemp, 2008).

\section{Materials and methods}

\subsection{Monitoring in the Horsens Fjord catchment and estuary}

The first Danish Action Plan for the Aquatic Environment was adopted in 1987, and the resulting monitoring program has been in place since 1989. Hence, more than $20 \mathrm{yr}$ of monitoring data are presently available for all major water bodies in Denmark (Larsen et al., 1999; Conley et al., 2002; Kronvang et al., 2008; Hinsby and Jørgensen, 2009; Markager et al., 2010; Hansen et al., 2011). In this study we use data from this program collected in the investigated catchment and data from a small agricultural research and monitoring site a few kilometers outside the catchment with intensive monitoring of tile drainage water and upper groundwater ( 1 to $5 \mathrm{~m}$ below ground surface).

Discharge and nutrient concentrations are measured in the Bygholm and Hansted streams at the two gauging stations (Fig. 1), covering the discharge and loadings from $56 \%$ of the catchment area. Water sampling in streams was normally conducted every second week and analyzed for TN, nitratenitrite-N, ammonium-N, TP, and dissolved orthophosphate. Instantaneous discharge $(Q)$ was measured 12 to 20 times per year using a low friction propeller, and daily discharge values were calculated using relationships between $Q$ and continuously measured fluctuations in water level $(H)$ in the streams.

Monitoring in the estuary was initiated in 1980, and systematically collected data exists from 1985 to 2007. Monitored parameters included profiles of salinity, temperature, chlorophyll fluorescence, and light attenuation from CTD (conductivity, temperature, depth) casts, as well as nutrient and chlorophyll concentrations from discrete water samples at two depths. Biomass measurements of underwater vegetation and the benthic invertebrates were performed together with enumeration of phytoplankton. The only rate measurement was made for phytoplankton primary production. The sampling frequency varied from 12 to 46 times per year. Generally, sampling and analytical procedures follow Danish and European standards and directives, i.e. most recently the requirements described in the EU's Monitoring Directive (EU, 2009). Selected data from the monitoring programs are shown in Tables 1 and 2. 


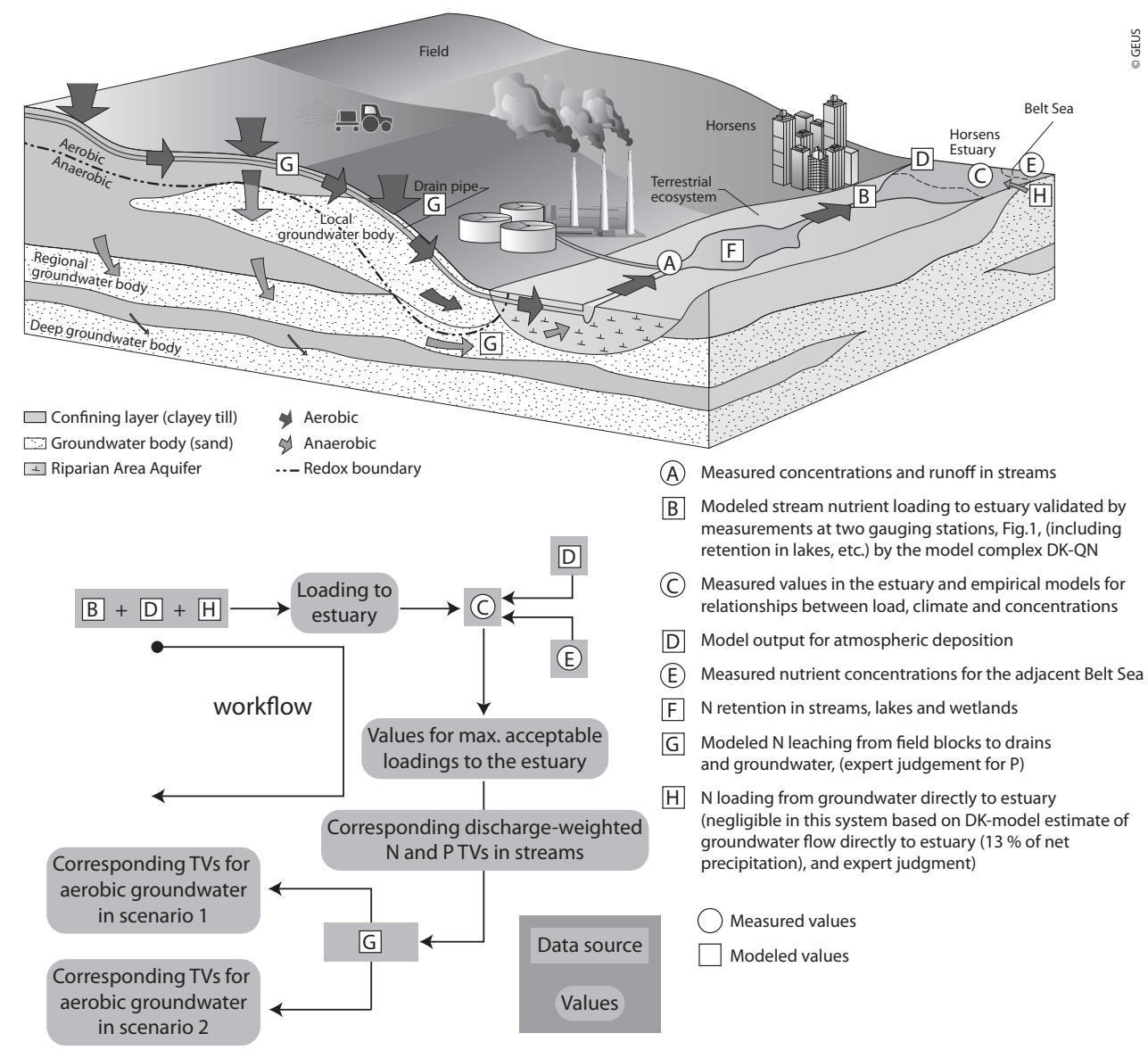

Fig. 2. Conceptual model of the catchment of Horsens estuary with indication of data and nutrient sources. The work process in calculation of threshold values (TVs) for streams and groundwater is indicated. The "DK-QN" model complex (or NLES \& DK-QN \& DK-model complex) is a combination of an empirical N leaching model (NLES, Kronvang et al., 2009b), an empirical monthly flow-weighted N concentration model from diffuse sources (DK-QN, Windolf et al., 2011), and a physically distributed integrated hydrological model (DK-model, Henriksen et al., 2003).

\subsection{Data analysis and development of conceptual model}

For the derivation of stream and groundwater threshold values, we apply a stepwise approach (Fig. 2). Firstly, the current $\mathrm{N}$ and $\mathrm{P}$ loadings to the estuary were estimated. Based on these values and empirical models for the relationships between loadings and nutrient concentrations, acceptable $\mathrm{N}$ and $\mathrm{P}$ loadings to the estuary were estimated. Secondly, two scenarios were constructed for achieving these values for annual nutrient loading. Finally, these annual loadings were converted to groundwater and stream threshold values using a catchment model and monitoring data for $\mathrm{N}$ and monitoring data and expert judgment for P (Fig. 2).

\subsubsection{Calculation of freshwater discharge, nutrient sources and loads}

Monthly freshwater discharge and transport of nutrients (TN and TP) are calculated using a linear interpolation method
(Kronvang and Bruun, 1996) by multiplying daily nutrient concentrations with mean daily discharge calculated from stage-discharge relationships, developed for each of the two gauging stations situated in the main stream inlets (Fig. 1). Land-based monthly nutrient loadings and freshwater discharge from the entire catchment to the Horsens estuary for the period 1984 to 2009 have been estimated utilizing data from the two gauged stations, and adding modeled monthly freshwater discharge and nutrient loadings from the ungauged part of the catchment by using the DK-QN model complex according to Windolf et al. (2011) (Fig. 2). The precision and bias of the estimated $\mathrm{N}$ loading from the gauged catchments is assessed to amount to $10 \%$ and $0 \%$, respectively, based on Monte Carlo evaluations of sampling frequencies and load estimates (Kronvang and Bruhn, 1996). The DK-QN model is a combination of an empirical nutrient loss model and the physically based, distributed and integrated hydrological "DK-model" ("the Danish National Water Resources Model”, Henriksen et al., 2003), which is 
Table 1. Average $\mathrm{N}$ and $\mathrm{P}$ concentrations in aerobic and anaerobic subsurface waters measured at agricultural monitoring sites (LOOP3 and LOOP4) for the period 2000-2005, compared to average N and P concentrations measured in the general groundwater monitoring program in the catchment of Horsens estuary for the monitoring period (1989-2009).

\begin{tabular}{|c|c|c|c|c|c|c|}
\hline Sample/“well” type & $\begin{array}{l}\mathrm{N} \\
\text { wells }^{\mathrm{a}} / \text { analyses }^{\mathrm{b}}\end{array}$ & $\begin{array}{l}\mathrm{NO}_{3}-\mathrm{N} \\
\mathrm{mg}^{-1}\end{array}$ & $\begin{array}{l}\mathrm{NH}_{4}-\mathrm{N} \\
\mathrm{mg}^{-1}\end{array}$ & $\begin{array}{l}\mathrm{DIN} \\
\mathrm{mg}^{-1}\end{array}$ & $\begin{array}{l}\mathrm{TN} \\
\mathrm{mg}^{-1}\end{array}$ & $\begin{array}{l}\mathrm{TP} \\
\mathrm{mg}^{-1}\end{array}$ \\
\hline \multicolumn{7}{|l|}{$\begin{array}{l}\text { Agricultural monitoring site } \\
\text { Average 2000-2005 }\end{array}$} \\
\hline $\mathrm{UZ}$ - suction cups $(\mathrm{LOOP} 3)^{\mathrm{c}}$ & - & 8.4 & - & - & $11^{\mathrm{d}}$ & 0.013 \\
\hline Drains $\left(\right.$ LOOP4) ${ }^{\mathrm{c}}$ & - & - & - & - & $12^{\mathrm{d}}$ & 0.050 \\
\hline $\begin{array}{l}\text { Drains/root zone leachate } \\
\text { (modeled, this study) }\end{array}$ & - & - & - & - & $15^{\mathrm{d}}$ & - \\
\hline All wells, $1.5-5$ m (LOOP3) & $22 / 444$ & 8.5 & 0.016 & 8.5 & 8.5 & 0.019 \\
\hline Aerobic wells (LOOP3) ${ }^{\mathrm{e}}$ & $20 / 414$ & 9.1 & 0.014 & 8.1 & 9.0 & 0.018 \\
\hline Anaerobic wells (LOOP3) & $2 / 30$ & 0.052 & 0.049 & 0.12 & 0.23 & 0.029 \\
\hline \multirow{2}{*}{\multicolumn{7}{|c|}{ Groundwater monitoring }} \\
\hline & & & & & & \\
\hline All wells with data in period & $119 / 183$ & 0.25 & 0.20 & 0.47 & - & 0.13 \\
\hline Aerobic wells & $7 / 12$ & 2.9 & 0.051 & 3.4 & - & 0.16 \\
\hline Anaerobic wells & $112 / 171$ & 0.068 & 0.21 & 0.28 & - & 0.13 \\
\hline
\end{tabular}

${ }^{a}$ Number of wells; ${ }^{b}$ maximum number of analyses; ${ }^{c}$ data from Grant et al. (2007); ${ }^{d}$ flow weighted concentrations - LOOP3 and LOOP4 are monitoring sites, which are located approximately 2 and $100 \mathrm{~km}$ from the investigated catchment, respectively, in areas with similar clayey soils; and "aerobic" and "anaerobic" wells are here defined as wells with $\mathrm{NO}_{3}-\mathrm{N} \geq 0.25 \mathrm{mg} \mathrm{l}^{-1}$ and $\mathrm{NO}_{3}-\mathrm{N}<0.25 \mathrm{mg} \mathrm{l}^{-1}$.

based on the integrated hydrological modeling system MIKE SHE (Abott et al., 1986; Graham and Butts, 2005), and calibrated against groundwater heads and runoff. The latest version (second generation) of the DK-model is developed with a grid size of $500 \mathrm{~m} \times 500 \mathrm{~m}$ (the first setup was $1000 \mathrm{~m} \times 1000 \mathrm{~m})$. In this study we have reduced the grid size even further to $250 \mathrm{~m} \times 250 \mathrm{~m}$, and used this resolution for the discharge estimation in both gaged and ungauged subcatchments. The surface/stream and subsurface water discharges from the catchment to the estuary, $87 \%$ and $13 \%$, respectively, are derived from DK-model simulations of the Horsens catchment.

Monthly nitrogen loadings were also modeled for the two gauged catchments, thus allowing a validation of the applied DK-QN model complex against measured nitrogen concentrations at the two gauged stations. Moreover, the nitrate leaching from the root zone (upper $1 \mathrm{~m}$ ) was calculated for the entire catchment of the Horsens estuary using the Danish empirical NLES leaching model, which performed well in a large inter-comparison with seven other well known nutrient models (Hejzlar et al., 2009; Kronvang et al., 2009b).

The total loadings were apportioned to sources according to Eq. (1) and Kronvang et al. (2005) (Table 3). The 9 discharges from point sources were measured at the outlets (industrial plants (IPs), waste water treatment plants (WWTPs), and fish farms (FFs)), or calculated based on treatment facilities and number of houses in each sub-catchment, and experience data for production of nutrients and reduction efficiency of treatment (SD). The atmospheric depositions of nitrogen to fresh surface waters $\left(A_{\text {fresh }}\right)$ and to the surface area of the Horsens estuary $\left(A_{\text {marin }}\right)$ were calculated based on national models for transportation and deposition (http: //www.air.dmu.dk). Natural background losses of TN (NB) were estimated as flow-weighted concentrations from sampling in streams draining uncultivated catchments. The gross nutrient emission to and load in streams $\left(L_{\mathrm{s}}\right)$ was calculated by the established model and includes the loads described by Eq. (1):

$L_{\mathrm{s}}=L_{\mathrm{agri}}+L_{\mathrm{nb}}+L_{\mathrm{ps}}+L_{\mathrm{af}}-R_{\mathrm{slw}}$

where $L_{\mathrm{S}}$ is the average loading of nutrients to the Horsens estuary estimated from diffuse sources and according to the combined use of monitoring and modeling data (B in Fig. 2), $L_{\text {agri }}$ is the nutrient load from agriculture ( $\mathrm{G}$ in Fig. 2), $L_{\mathrm{nb}}$ is the natural background load of nutrients from non-agricultural areas, $L_{\mathrm{ps}}$ is the nutrient load from point sources, $L_{\mathrm{af}}$ is the direct atmospheric deposition on surface freshwater (D in Fig. 2), and $R_{\text {slw }}$ is the retention of nutrients in the catchment after their emission to surface waters ( $\mathrm{F}$ in Fig. 2).

\subsubsection{Estimating maximum acceptable nutrient loads to Horsens estuary}

The estimation of maximum acceptable loads to Horsens estuary was based on empirical models for relationships between $\mathrm{N}$ and $\mathrm{P}$ loadings and resulting $\mathrm{N}$ and $\mathrm{P}$ concentrations (effects) in the estuary (Fig. 4). The specific effects ( $y$-variable) evaluated were annual mean concentrations of TN and P, and mean concentrations of DIN (dissolved 
Table 2. Average $\mathrm{N}$ and $\mathrm{P}$ concentrations in streams and coastal waters, 2000-2005.

\begin{tabular}{|c|c|c|c|c|}
\hline Surface water sampling station & $\begin{array}{l}\text { DIN } \\
\mathrm{mg} \mathrm{l}^{-1}\end{array}$ & $\begin{array}{l}\mathrm{TN} \\
\mathrm{mg} \mathrm{l}^{-1}\end{array}$ & $\begin{array}{l}\mathrm{PO}_{4}-\mathrm{P} \\
\mathrm{mg} \mathrm{l}^{-1}\end{array}$ & $\begin{array}{l}\mathrm{TP} \\
\mathrm{mg} 1^{-1}\end{array}$ \\
\hline Hansted Stream - $(\mathrm{FWm} / \mathrm{FWs})^{\mathrm{a}}$ & 4.9/- & $5.6 / 5.5^{\mathrm{b}}$ & $0.041 /-$ & $0.10 /-$ \\
\hline Bygholm Stream - $(\mathrm{FWm} / \mathrm{FWs})^{\mathrm{a}}$ & $7.4 /-$ & $8.0 / 6.6^{\mathrm{b}}$ & $0.072 /-$ & $0.14 /-$ \\
\hline Streams ungauged catchm. $(\mathrm{FWm} / \mathrm{FWs})^{\mathrm{a}}$ & $-1-$ & $-16.2^{\mathrm{b}}$ & $-1-$ & $-1-$ \\
\hline Horsens inner estuary & 0.24 & 0.55 & 0.013 & 0.056 \\
\hline Horsens outer estuary & 0.14 & 0.39 & 0.011 & 0.046 \\
\hline Belt Sea & 0.04 & 0.25 & 0.012 & 0.040 \\
\hline
\end{tabular}

${ }^{\mathrm{a}}$ Flow weighted, $\mathrm{FWm}=$ measured concentration, $\mathrm{FWs}=$ simulated concentration; ${ }^{\mathrm{b}}$ measured and simulated stream concentrations include diffuse and point sources.

Table 3. Nitrogen and phosphorus sources and loadings to the Horsens estuary, 2000-2005, (partly from BLST, 2010).

\begin{tabular}{|c|c|c|c|c|}
\hline & $\begin{array}{r}\mathrm{N} \\
\mathrm{t}\end{array}$ & $\begin{array}{l}P \\
t\end{array}$ & $\begin{array}{l}\mathrm{N} \\
\%\end{array}$ & $\begin{array}{l}\mathrm{P} \\
\%\end{array}$ \\
\hline Natural background (NB) & 179 & & 17 & \\
\hline Agriculture (AGRI) & 704 & 16.2 & 65 & 69 \\
\hline Scattered dwellings (SD) & 15 & & 1.4 & \\
\hline Industrial plant discharges (IP) & 0 & 0 & 0 & 0 \\
\hline Fish farming (freshwater) $\left(\mathrm{FF}_{\text {fresh }}\right)$ & 0.5 & 0.07 & 0.05 & 0.3 \\
\hline Fish farming (marine) $\left(\mathrm{FF}_{\text {marin }}\right)$ & 11 & 1.39 & 1.0 & 5.9 \\
\hline Waste water treatment plants (WWTP) & 64 & 1.9 & 5.9 & 8.1 \\
\hline Urban stormwater runoff (USR) & 15 & 3.5 & 1.4 & 15 \\
\hline Atmospheric deposition on freshwater bodies $\left(A_{\text {fresh }}\right)$ & 4.1 & 0.08 & 0.4 & 0.3 \\
\hline Atmospheric deposition on marine waters $\left(A_{\text {marin }}\right)$ & 94 & 0.24 & 8.7 & 1.0 \\
\hline Sum of all sources & 1086 & 23.4 & 100 & 100 \\
\hline
\end{tabular}

inorganic nitrogen $\left.=\mathrm{NO}_{2}-\mathrm{N}+\mathrm{NO}_{3}-\mathrm{N}+\mathrm{NH}_{4}-\mathrm{N}\right)$ from May through October and DIP (dissolved inorganic phosphorus $=\mathrm{PO}_{4}-\mathrm{P}$ ) from March through July (Table 4). The periods for DIN and DIP correspond approximately to the periods were $\mathrm{N}$ or $\mathrm{P}$ limitation of phytoplankton occur in the estuary (data not shown). The empirical models were developed with an iterative multiple linear regression procedure working on standardized time series (zero mean and a standard deviation equal to one) for both dependent and independent variables. The explanatory variables ( $x$-variables) were $\mathrm{N}$ and $\mathrm{P}$ loads, water temperature, wind speed (cubed daily mean values), surface irradiance, salinity (used as a proxy for water exchange with the adjacent Belt Sea) and the North Atlantic Oscillation Index (NAO, http://www.cru.uea.ac.uk/ $\sim$ timo/projpages/nao_update). These variables represent the major external factors governing the conditions in the estuary, i.e. nutrient loadings, climatic forcing and water exchange. Each explanatory variable was calculated as mean values for eleven different time periods prior to and/or including the period for the response variable in order to allow for time lag between loads and resulting effects in the estuary. The eleven periods were periods 1 to 5 , the periods for the response variable including $0,1,2,4$ and 8 months before, and period 6, all months back to January in the previous year; periods 7 to 11 were periods ending when the response period started and starting 1, 2, 4 and 8 month before, and January in the previous year. This method gave $7 \times 11$ potential explanatory variables. A forward selection procedure adopted from Broadhurst et al. (1997) was used to select the explanatory parameters providing the best model fit. A jack-knifing procedure was used to test all variables and all combinations of years, and the best explanatory variables were chosen based on root mean square error of cross validation (RMSECV). RMSECV were also used to determinate the maximum number of explanatory variables (between two and five) without overparameterisation of the model. Outliers where identified from the jack-knifing procedure according to Martens and Dardenne (1998). Nitrogen and phosphorous loadings were always chosen as the first variable for their respective concentrations, and only one variable for each class of explanatory variables was chosen, but otherwise the selection procedure for explanatory variables was based on RMSECV. The procedure stopped when further explanatory variables did not improve the model based on RMSECV (two to four explanatory variables were used). Time series from 1985 to 2006 were used, i.e. $22 \mathrm{yr}$, however, the last four 
years where not used in the parameter selection procedure but retained for validation. After validation of the explanatory parameter selection, a final estimation of the regression coefficients was done including all $22 \mathrm{yr}$. The final results from the models are coefficients for the effects of changes in response variables per unit change in loadings (\% change in response variable $/ \%$ change in loading), adjusted for effects of inter-annual variability in climatic conditions. These coefficients were subsequently used to estimate the values for response variables under reduced loadings assuming average climatic conditions, i.e. the final model equations were used as scenarios where $\mathrm{N}$ and $\mathrm{P}$ loads varied, but with climatic variables set to their average value in the data set. Finally, the maximum acceptable loads to the estuary were estimated using the calculated relationships between DIN and DIP mean concentrations, and the percentage of days with $\mathrm{N}$ and $\mathrm{P}$ limitations in the estuary (see Sect. 4.3 and Fig. 8 for estimation of $\mathrm{N}$ and $\mathrm{P}$ limitations and Sect. 5.2 for a discussion of good ecological status). Nutrient limitations are assumed to occur at $14 \mu \mathrm{g} \mathrm{DIN} 1^{-1}$ and $6.2 \mu \mathrm{g} \mathrm{DIP} 1^{-1}$. These values are equivalent to $\mathrm{K}_{\mathrm{m}}$ values for growth in a Michaelis-Menten expression of $1 \mu \mathrm{mol} 1^{-1}$ for DIN and $0.2 \mu \mathrm{moll}^{-1}$ for DIP, based on values given by MacIsaac and Dugdale (1969), Eppley et al. (1969), Falkowski (1975) and Quile et al. (2011).

\subsection{Scenarios of mitigation measures}

The reduction targets for nutrient loadings calculated for the Horsens estuary can be accomplished by utilizing different mitigation measures in the catchment, and it is important to note that the actual selection of applied mitigation measures will affect the calculated groundwater threshold value for TN. The reason for this is that the chosen measures may include and take advantage of subsurface reduction (retention) processes to various degrees. Generally, the most strict groundwater threshold values would be established if subsurface retention is not increased and the reduction in nutrient loading is solely to be obtained by reducing the nutrients leaching from agricultural soils. Groundwater threshold values can be allowed to be higher if in addition other measures such as introduction of uncultivated buffer zones, restoration of wetlands along streams and reduction in other significant nutrient sources were applied to help reduce the nutrient loading to streams and ultimately the estuary. We have evaluated two possible scenarios to illustrate how the choice of mitigation measure will influence the derived groundwater threshold value for TN:

Scenario 1: Assumes that the entire reduction target for $\mathrm{N}$ and $\mathrm{P}$ is directed against the diffuse sources in the catchment, i.e. losses from fields. This scenario results in the lowest (most strict) groundwater threshold values.

Scenario 2: Measures are imposed on point sources, direct atmospheric deposition (through lower emission of ammonia from agriculture/manure) and diffuse sources. Furthermore, construction/restoration of wetlands and uncultivated buffer zones along streams were included for additional removal of nutrients. As this scenario utilizes further nitrogen reduction from other sources, it allows higher threshold values in aerobic groundwater.

\subsection{Derivation of stream threshold values}

In contrast to groundwater threshold values, stream threshold values are not sensitive to the selected nutrient management options in the investigated catchment. The flowweighted stream concentrations simply have to be reduced by the same relative amount as required for the estuary as the stream inputs constitute approximately $90 \%$ of the TN input to the estuary (Table 3), while the groundwater threshold values depend on how and where remediation measures are applied and nutrients are removed/immobilized (Sect. 3.5). Hence, groundwater thresholds for e.g. nitrate (or TN) derived to ensure a good ecological status of the associated estuary, can be significantly higher if efficient wetlands for removal of nitrate before discharge to streams or the estuary are constructed (see discussions in Sects. 3.3 and 5.3).

To estimate the current TN loading from streams to the estuary and the required threshold values, we have applied an empirical model for estimating monthly flow-weighted TN concentrations in freshwater discharge to minor streams. The model was developed based on nitrogen data for 83 small agricultural catchments without lakes or wetlands and data for the period 1990 to 2009 using an approach described by Kronvang et al. (1995), Andersen et al. (2005), and Windolf et al. (2011). The retention of TN in streams, lakes and wetlands was calculated utilizing different models and expert judgments as described in Windolf et al. $(1996,2011)$ and Kronvang et al. (2005). The modeling complex allowed a model estimation of gross and net stream flow-weighted concentrations taking into consideration the nutrient retention in the 5 larger lakes situated in the catchment, of which the 2 largest are situated downstream the two monitoring stations just before river water enters the estuary (Fig. 1). Net inlet freshwater nitrogen threshold values for Horsens estuary were calculated utilizing this model complex for the two scenarios. The threshold values for TP were calculated as net flow-weighted concentrations.

\subsection{Derivation of groundwater threshold values}

Groundwater threshold values depend on the application of possible mitigation measures as described in Sect. 3.3. The threshold value has to be calculated for aerobic groundwater as the major nitrogen species in groundwater, nitrate, is reduced to unreactive $\mathrm{N}_{2}$ at the redox boundary.

Dissolved inorganic nitrogen $\left(\mathrm{DIN}=\mathrm{NO}_{2}-\mathrm{N}+\mathrm{NO}_{3}-\mathrm{N}+\right.$ $\mathrm{NH}_{4}-\mathrm{N}$ ) in anaerobic groundwater in the investigated catchment is primarily present as ammonia at concentrations that are generally 1-2 orders of magnitude lower than the DIN concentrations in aerobic groundwater, where nitrate is the 
Table 4. Coefficients from the empirical models of the estuary. The maximum observed concentrations ( $\left.\mu \mathrm{g} 1^{-1}\right)$ in the period 1985 to 2006 (year in brackets), and estimated values with the empirical models and normalized climate for 2001-2005, with target loads for good ecological status, and with background loads. Loads for nitrogen and phosphorous are given in brackets in $\mathrm{t}$ (metric tonne) of $\mathrm{N}$ or $\mathrm{Pyr}^{-1}$.

\begin{tabular}{|c|c|c|c|c|c|c|c|c|}
\hline & \multicolumn{4}{|c|}{ Inner estuary } & \multicolumn{4}{|c|}{ Outer estuary } \\
\hline & $\begin{array}{r}\mathrm{TN} \\
1-12^{*}\end{array}$ & $\begin{array}{r}\text { DIN } \\
5-10^{*}\end{array}$ & $\begin{array}{r}\mathrm{TP} \\
1-12^{*}\end{array}$ & $\begin{array}{r}\text { DIP } \\
3-7^{*}\end{array}$ & $\begin{array}{r}\mathrm{TN} \\
1-12^{*}\end{array}$ & $\begin{array}{r}\text { DIN } \\
5-10^{*}\end{array}$ & $\begin{array}{r}\mathrm{TP} \\
1-12^{*}\end{array}$ & $\begin{array}{r}\text { DIP } \\
3-7^{*}\end{array}$ \\
\hline $\begin{array}{l}\text { Coefficients } \\
\mu \mathrm{g} 1^{-1}\left(\mathrm{t} \mathrm{N} \text { or } \mathrm{Pyr}^{-1}\right)^{-1}\end{array}$ & $\begin{array}{r}0.20 \\
(\mathrm{~N})\end{array}$ & $\begin{array}{r}0.023 \\
(\mathrm{~N})\end{array}$ & $\begin{array}{r}0.46 \\
(\mathrm{P})\end{array}$ & $\begin{array}{r}0.20 \\
(\mathrm{P})\end{array}$ & $\begin{array}{r}0.13 \\
(\mathrm{~N})\end{array}$ & $\begin{array}{r}0.017 \\
(\mathrm{~N})\end{array}$ & $\begin{array}{r}0.33 \\
(\mathrm{P})\end{array}$ & $\begin{array}{r}0.07 \\
(\mathrm{P})\end{array}$ \\
\hline $\begin{array}{l}\text { Maximum obs. values } \\
1985-2006\left(\mu \mathrm{g} \mathrm{l}^{-1}\right)\end{array}$ & $\begin{array}{r}836 \\
(1990)\end{array}$ & $\begin{array}{r}107 \\
(1993)\end{array}$ & $\begin{array}{r}97 \\
(1986)\end{array}$ & $\begin{array}{r}21 \\
(1988)\end{array}$ & $\begin{array}{r}646 \\
(1990)\end{array}$ & $\begin{array}{r}52 \\
(1993)\end{array}$ & $\begin{array}{r}58 \\
(1986)\end{array}$ & $\begin{array}{r}13 \\
(1993)\end{array}$ \\
\hline $\begin{array}{l}\text { Estimated values for } \\
\text { 2001-2005 }(\mathrm{N}=1086, \mathrm{P}=23.4 \text {, } \\
\text { Table 3) }\end{array}$ & 567 & 32 & 48 & 8.1 & 421 & 14 & 35 & 6.9 \\
\hline $\begin{array}{l}\text { Estimated values with target } \\
\text { loads }(\mathrm{N}=560, \mathrm{P}=13)\end{array}$ & 462 & 20 & 43 & 6.0 & 355 & 5.3 & 31 & 6.2 \\
\hline $\begin{array}{l}\text { Estimated values with } \\
\text { background loads }(\mathrm{N}=252 \text {, } \\
\mathrm{P}=8.1)\end{array}$ & 401 & 12 & 41 & 5.0 & 316 & 0.1 & 30 & 5.9 \\
\hline
\end{tabular}

* The numbers refer to the months over which the average values are calculated.

dominant nitrogen species (Table 1). Hence, the major part of the TN load to streams is generally nitrate originating from shallow aerobic groundwater that discharges either directly or via drainage ditches or tiles to the stream (Fig. 2). As there are only a few monitoring wells in aerobic groundwater in the investigated catchment, the leaching of nitrate from the root zone ( $1 \mathrm{~m}$ below surface) was modeled utilizing the Danish developed leaching model (NLES4) (Kristensen et al., 2008; Kronvang et al., 2008). The model was applied to a large number of combinations of soil types, crop types, climate, etc., and the $\mathrm{N}$ leaching results were extrapolated to field block level (ca. 8 ha) within the catchment of the Horsens estuary based on field block information in agro-statistical data and climatic data for the agro-hydrological year of 2005 (1 April 2005 to 31 March 2006). For the agro-hydrological years 2000 to 2004, distributed data for nitrate leaching was estimated using agro-statistical data for 2005 because no specific regional data was available for 2000-2004. However, specific climate data for the years 2000 to 2004 was applied in the estimation of nitrate leaching. Nitrogen retention in groundwater was estimated by the differences between modeled net outlet of TN to surface waters from diffuse sources and the nitrate leaching from the root zone of the entire catchment.

For TP the situation is different as $\mathrm{P}$ concentrations are often up to one order of magnitude higher in deeper anaerobic aquifers compared to shallow aerobic aquifers, and the phosphorus sources in anaerobic groundwater are generally natural. While the sources and transport of the different $\mathrm{N}$ species are generally quite well known, the sources and transport of the various components of the measured TP are still poorly understood for subsurface as well as surface waters
(Kronvang et al., 2007). As the major part of phosphorus in groundwater is natural, it is neither relevant nor possible to derive a groundwater threshold value to control the anthropogenic input.

\section{Results}

\subsection{Measured and modeled data from surface and subsurface waters}

Nitrogen and phosphorus monitoring data for subsurface waters (suction cups, tile drains and monitoring wells) and surface waters (streams and estuary) are shown for comparison in Tables 1 and 2, respectively. Model simulated concentrations for TN are compared to measured concentrations in Table 2 for the two gauged sub-catchments, and for the Hansted stream in Fig. 3. The simulated concentrations for the Bygholm stream are not as good as for the Hansted stream, but are still quite good (Nash-Sutcliff $=0.49$ ), and as the model has not been calibrated on the measurements, we consider it as a validation of our model setup. The mean precision and bias from the validation of the model for TN at the two gauged stream stations are calculated to amount to $15.2 \%$ and $10.5 \%$, respectively. Combining the uncertainty of the TN loading from both gauged and ungauged catchment areas of Horsens estuary reveals a mean precision and bias amounting to $9 \%$ and $5 \%$, respectively. 


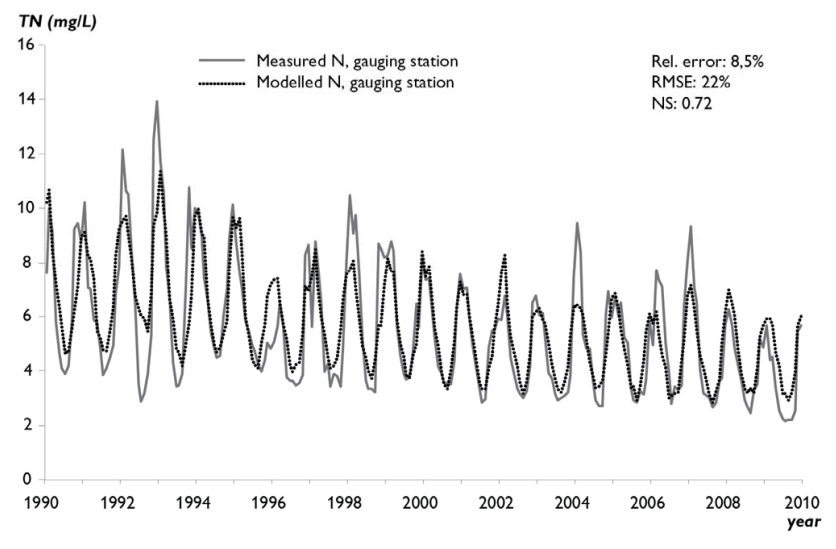

Fig. 3. Measured and simulated TN concentrations at the gauging station on Hansted stream (see Fig. 1).

\subsection{Development and current status for nutrient sources, loadings and sinks}

The average land based nitrogen load to the estuary was $1770 \mathrm{t} \mathrm{yr}^{-1}$ between 1984 and 1992, corresponding to an average weighted concentration in the streams of $11.1 \mathrm{mg} \mathrm{N}^{-1}$ (Fig. 4). This concentration is 8-10 times higher than the estimated natural background loss. From 1993 the effects of abatement measures for nitrogen losses in agriculture became visible as nitrogen concentrations were decreasing in the freshwater discharge to the estuary, reaching $5.1 \mathrm{mg} \mathrm{N}^{-1}$ in 2009 (the simulated annual average for the investigated baseline period 2000-2005 is $6.2 \mathrm{mg} \mathrm{N}^{-1}$ ) (Fig. 4). This concentration includes nitrogen from diffuse sources as well as point sources (sewage).

The DK-model simulations estimate that approximately $13 \%$ of the net precipitation in the catchment to the Horsens estuary is discharged directly to the estuary via groundwater (Sect. 3.2.1). As the redox boundary generally is located a few meters below the water table in the catchment, we estimate that the major part of the groundwater that discharges directly to the estuary is reduced and therefore is without nitrate. Hence, we argue that the nitrogen loading to the estuary directly from groundwater most probably is insignificant.

The most important source of $\mathrm{N}$ was agriculture, being responsible for $65 \%$ of the TN loading (Table 3). The average $\mathrm{N}$ loss from agricultural areas in the catchment amounted to $56 \mathrm{~kg} \mathrm{ha}^{-1} \mathrm{yr}^{-1}$ during the period 2001 to 2005 , the period with the most detailed data and modeling. The second most important $\mathrm{N}$ source was the estimated loss of $\mathrm{N}$ from natural background sources, which amounted to $17 \%$. The loadings from point sources in the catchment and marine fish farming amounted to $105 \mathrm{t} \mathrm{N}$, or only $9.7 \%$ of the TN loading (Table 3). Atmospheric deposition of $\mathrm{N}$ directly on the estuarine waters amounted to $8.7 \%$ of the TN loading.

TP loadings to the Horsens estuary were, on average, $95 \mathrm{tPyr}^{-1}$ from 1984 to 1987 (Fig. 4). Introduction of tertiary treatment of wastewater caused a sharp decline in 1988 , and loadings continued to decline until 1995, reaching an average loading of $28 \mathrm{t} \mathrm{Pyr}^{-1}$ during 1995 to 2006 (Fig. 4). The average TP loading to the Horsens estuary amounted to $23.4 \mathrm{t} \mathrm{P}$ during the period 2001 to 2005 . The diffuse sources of $\mathrm{P}$ (background, agriculture and scattered dwellings) were the dominant source, amounting to $16.2 \mathrm{t} P$, or $69 \%$ of the total loading (Table 3 ). The second most important $\mathrm{P}$ source was urban runoff $(15 \%)$, followed by discharges from waste water treatment plants $(8 \%)$, and fish farming in the estuary $(6 \%)$.

The modeled average annual $\mathrm{N}$ leaching from the root zone (1 $\mathrm{m}$ depth) on agricultural land in three sub-catchments to the Horsens estuary is shown in Table 5. The $\mathrm{N}$ leaching varies from year to year and from sub-catchment to subcatchment, being dependent on factors such as climate, soil types, crop types, and the application of chemical fertilizer and manure. The total annual $\mathrm{N}$ leaching from both agricultural and non-agricultural land in the entire catchment to the Horsens estuary is shown in Table 6. The $\mathrm{N}$ leaching varies considerably from year to year, being lowest in 2005 $(1390 \mathrm{t} \mathrm{N})$ and highest in $2001(3384 \mathrm{t} \mathrm{N})$. The $\mathrm{N}$ transport in the streams was considerably lower than the modeled $\mathrm{N}$ leaching (Table 6) due to $\mathrm{N}$ removal in groundwater within the catchment. The average annual $\mathrm{N}$ removal in groundwater amounts to $53 \%$ of the average annual $\mathrm{N}$ leached from the root zone, compared to $21 \%$ removal in surface waters (streams, lakes, and wetlands) (Table 6). The resulting modeled annual $\mathrm{N}$ loading and flow-weighted concentrations in inlet waters from diffuse sources to the Horsens estuary are shown in Table 6 . These flow-weighted concentrations vary between 4.4 and $6.0 \mathrm{mg} \mathrm{N}^{-1}$ in the period 2000 to 2005 (the period with detailed modeling). The average annual $\mathrm{N}$ fluxes from fields to the estuary are shown in Fig. 5. An average of $64 \%$ of the $\mathrm{N}$ emissions from the diffuse sources are removed during the transport from field to estuary.

\subsection{Relationships between nutrient loads and environmental status of Horsens estuary}

Figure 7 illustrates the relation between observed and modeled DIN concentrations in the estuary and shows that $70 \%$ of the variability in DIN concentrations can be explained by $\mathrm{N}$ loadings and wind stress. The nutrient concentrations in the estuary have declined concurrent with the decrease in loadings (Figs. 4 and 6). The patterns in the residuals (Fig. 6b) reveal that negative residuals are mainly found in the beginning and the end of the period, and positive residuals in the middle, starting in 1992 and continuing for about $10 \mathrm{yr}$. This could indicate a non-steady state situation where the nutrient pool in the sediment, for a period of approximately ten years, leaks nutrients to the water column (Lomstein et al., 1998; Christensen et al., 2000) before a new equilibrium is established between external loadings and the sediment pool. 

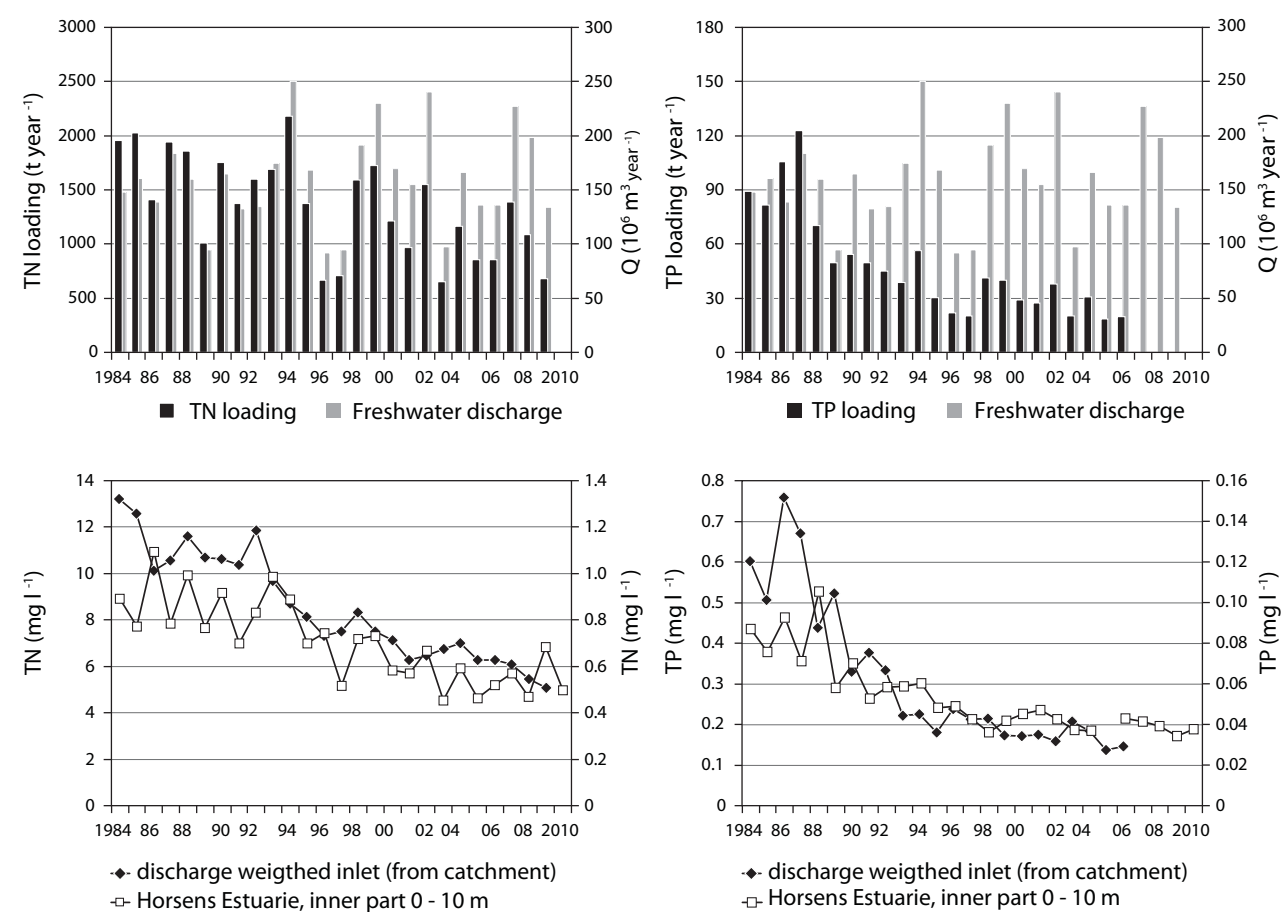

Fig. 4. Historical development of freshwater discharge and TN and TP loadings to Horsens estuary (upper figures), discharge weighted concentrations in the freshwater inlet to the estuary and annual average concentrations $(0-10 \mathrm{~m})$ in the inner part of the estuary (lower figures), 1984-2010.

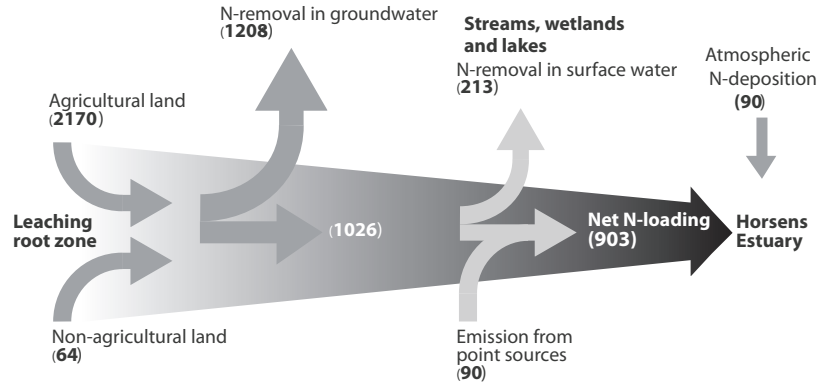

Fig. 5. Modeled nitrogen fluxes in the catchment of Horsens estuary and the net loading to the estuary, showing annual averages for the baseline period 2000-2005. Numbers in parenthesis are $\mathrm{t}$.

Decreasing chlorophyll concentrations were also observed in the inner part of the estuary for the spring periods (March to June) from 1985 to 1992 following the drop in phosphorous loadings (data not shown). This is in agreement with indications of phosphorous as the primary limiting nutrient in the spring. However, in the outer part of the estuary and for the late summer period (July to October) the chlorophyll concentrations did not respond to the decrease in loadings and nutrient concentrations. Water clarity improved from 1985 to 1995 in both parts of the estuary in the spring period (April to June). The diffuse attenuation coefficient $\left(K_{\mathrm{d}}\right)$ decreased from $1.15 \mathrm{~m}^{-1}$ to $0.55 \mathrm{~m}^{-1}$ in the inner part of estuary and from 0.81 to $0.33 \mathrm{~m}^{-1}$ in the outer part. Again, this is most likely a response to the lower phosphorous loadings and a general pattern observed in Danish estuaries where conditions in the spring are more directly influenced by loadings, compared to conditions later in the summer where available nutrients are more governed by internal processes, e.g. release from the sediments (Lomstein et al., 1998; Christensen et al., 2000). Since $1995 K_{\mathrm{d}}$ has shown an increasing trend for the spring period, and $\mathrm{K}_{\mathrm{d}}$ values from July to September have been variable with average values of 0.78 and $0.50 \mathrm{~m}^{-1}$ in the inner and outer part, respectively (Table 4), but no trends have been observed. Similarly, no positive developments have been observed for underwater vegetation (mainly eelgrass, Zostera marina, L.), which reached its lowest levels during the period 2000 to 2003 . However, some improvements have been seen in 2007 to 2008 (Markager et al., 2010). Thus, despite significant reductions in nutrient loads and concentrations we only observe minor positive effects on the biological components in the ecosystem. Major improvements would require that the former eelgrass meadows come back and that water clarity and oxygen conditions improve substantially (see Sect. 5.2 for a discussion of good ecological status).

Several mechanisms can explain the lack in biological response to the decrease in loads. A pool of nutrients in the sediment is probably the reason for a delay in the decline of nutrient concentrations as described above. Generally, 
Table 5. Model calculated annual average $\mathrm{N}$ leaching and flowweighted $\mathrm{N}$ concentrations in root zone water (1 $\mathrm{m}$ depth) from agricultural land within the three sub-catchments to the Horsens estuary.

\begin{tabular}{lrr}
\hline $\begin{array}{l}\text { Agro-hydrological } \\
\text { years }\end{array}$ & $\begin{array}{r}\text { Average N leaching } \\
\text { from root zone on } \\
\text { agricultural land } \\
\left(\mathrm{kg} \mathrm{ha}^{-1} \mathrm{yr}^{-1}\right)\end{array}$ & $\begin{array}{r}\text { N concentration from root } \\
\text { zone on agricultural } \\
\text { land }\left(\mathrm{mg} \mathrm{l}^{-1}\right)\end{array}$ \\
\hline Hansted sub-catchment $\left(136 \mathrm{~km}^{2}\right)$ & \\
\hline 2000 & 48.1 & 15.9 \\
2001 & 85.3 & 18.7 \\
2002 & 50.5 & 15.6 \\
2003 & 52.8 & 22.7 \\
2004 & 73.4 & 16.9 \\
2005 & 35.1 & 22.6 \\
\hline Average & 57.5 & 18.7 \\
\hline Bygholm sub-catchment $\left(154 \mathrm{~km}^{2}\right)$ & \\
\hline 2000 & 48.2 & 16.5 \\
2001 & 98.0 & 18.5 \\
2002 & 53.3 & 22.1 \\
2003 & 55.5 & 17.5 \\
2004 & 78.0 & 20.5 \\
2005 & 39.0 & 18.4 \\
\hline Average & 62.0 & 17.1 \\
\hline Ungauged sub-catchment $\left(228 \mathrm{~km}^{2}\right)$ & 16.8 \\
\hline 2000 & 42.8 & 26.9 \\
2001 & 73.0 & 20.4 \\
2002 & 43.1 & \\
2003 & 42.6 & \\
2004 & 63.9 & \\
\hline Average & 31.3 & \\
\hline & 49.5 & \\
\hline
\end{tabular}

positive residuals for nitrogen, i.e. observed concentrations that are higher than expected from the models, were seen over nine years from 1992, when nitrogen concentrations in the streams began to drop, until 2001 (Fig. 6). This could indicate a transition period where a positive net nitrogen flux out of the sediments is important. Another important mechanism is resuspension of sediment particles after the former underwater meadows of eelgrass are lost. A third factor can be derived from Fig. 8 showing the relationship between concentrations of inorganic nutrients and number of days with nutrient limitations as defined in Sect. 3.2.2 ; for average DIN concentrations (May-October) above $35 \mu \mathrm{g}^{-1}$, the percent of the time with $\mathrm{N}$ limitation is rather constant (Fig. 8). Thus, DIN is in surplus and only occasionally limits the growth of phytoplankton during the growth season, particularly in the inner part of the estuary (Fig. 8a). Only when the average DIN concentrations fall below about $35 \mu \mathrm{g} 1^{-1}$ will $\mathrm{N}$ limitation become significant. This pattern indicates that the reductions in $\mathrm{N}$ loads have removed a surplus of nitrogen in the estuary, but have until recently not been sufficient to introduce significant $\mathrm{N}$ limitation of phytoplankton growth. A similar figure for $\mathrm{P}$ shows a more linear increase in the time

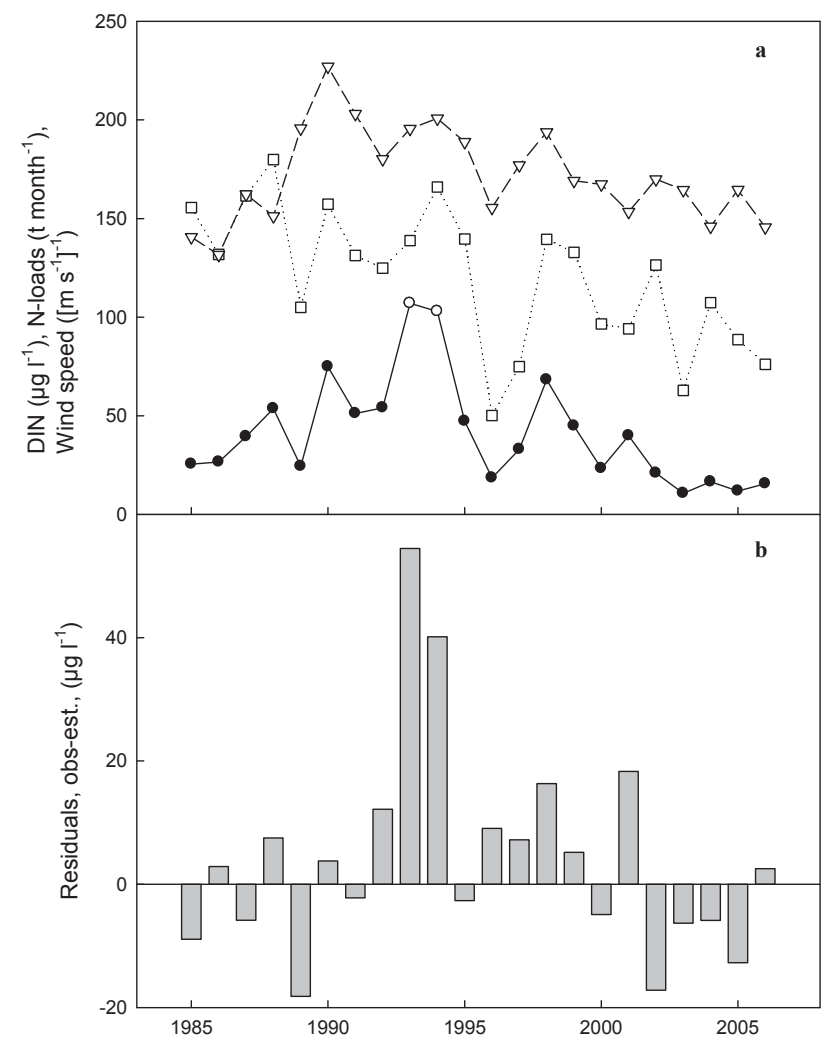

Fig. 6. (a) Time series of inorganic nitrogen concentrations (DIN) from May to October (filled circles, response variable, the two open circles indicate outliers from the model, see Fig. 7), average of monthly TN loads from January to October (open squares, $\mathrm{x}$ variable, $\mathrm{t} \mathrm{month}^{-1}$ ) and wind speed raised to the third (open triangles, $\mathrm{x}$-variable, $\left.\left(\mathrm{m} \mathrm{s}^{-1}\right)^{-1}\right)$. (b) residual from model.

period with increasing limitation when average concentrations decline (Fig. 8b), and the inner and outer part of the estuary have approximately the same concentrations of DIP (Table 4).

\subsection{Maximum acceptable $N$ and $P$ loads}

Maximum acceptable total loads were defined on the basis of Fig. 8 and the assumption that nutrient limitation of phytoplankton growth is necessary during most of the growth season in order to achieve good ecological status (see Sect. 5.2 for a discussion of good ecological status). We find it necessary to apply a "dual-nutrient reduction strategy" wherein both $\mathrm{N}$ and P loads are reduced (Boynton and Kemp, 2008; Conley et al., 2009) in order to ensure good ecological status, and we have defined the average DIN and DIP concentrations where nutrient limitations occur during $2 / 3$ of the growth season as a reasonable threshold (Fig. 8). The corresponding threshold values are $21 \mu \mathrm{g} \mathrm{DIN} 1^{-1}$ and $7 \mu \mathrm{gDIP}^{-1}$ for the inner and outer estuary, respectively, calculated from the data in Figs. $8 \mathrm{a}$ and $7 \mathrm{~b}$. Once we have defined the target value, the corresponding loads can be calculated from the empirical 
Table 6. Modeled N leaching and gross N emissions from diffuse sources within the catchment of Horsens estuary during the period 20002005. The TN removal in groundwater and surface water is also shown for the same period. Loadings are in $t$, concentrations in mg $1^{-1}$. Numbers in parenthesis indicate the percentage of amount leached from the root zone.

\begin{tabular}{|c|c|c|c|c|c|c|}
\hline $\begin{array}{l}\text { Agro- } \\
\text { hydrological } \\
\text { years }\end{array}$ & $\begin{array}{l}\mathrm{N} \text { leaching } \\
\text { from the } \\
\text { root zone }\end{array}$ & $\begin{array}{l}\text { Modeled } \\
\text { gross } \\
\mathrm{N} \text { emissions } \\
\text { from diffuse } \\
\text { sources }\end{array}$ & $\begin{array}{l}\mathrm{N} \text { removal } \\
\text { in ground } \\
\text { water }^{\mathrm{a}}\end{array}$ & $\begin{array}{l}\mathrm{N} \text { removal } \\
\text { in surface } \\
\text { water }^{\mathrm{b}}\end{array}$ & $\begin{array}{l}\text { Net } \\
\mathrm{N} \text { loading } \\
\text { to Horsens } \\
\text { estuary }\end{array}$ & $\begin{array}{l}\text { Average } \\
\text { stream } \\
\text { flow-weighted } \\
\mathrm{N} \text { concentrations }{ }^{\mathrm{d}} \\
\text { at inlet to } \\
\text { estuary }\end{array}$ \\
\hline 2000 & 1851 & 1070 & $780(42)$ & $224(21)$ & 846 & 5.6 \\
\hline 2001 & 3384 & 1519 & $1865(55)$ & $263(17)$ & 1256 & 6.0 \\
\hline 2002 & 1952 & 1014 & 937 (48) & $205(20)$ & 809 & 4.7 \\
\hline 2003 & 1973 & 793 & $1180(60)$ & 189 (24) & 605 & 5.0 \\
\hline 2004 & 2856 & 1093 & $1763(62)$ & $233(21)$ & 860 & 5.1 \\
\hline 2005 & 1390 & 669 & $721(52)$ & $168(25)$ & 501 & 4.4 \\
\hline Average & 2234 & 1026 & $1208(53)$ & $213(21)$ & 813 & 5.1 \\
\hline
\end{tabular}

models, assuming that climatic variables in the models are equal to their long term mean values. These are a $\mathrm{N}$ load of $560 \mathrm{t} \mathrm{yr}^{-1}$ and a $\mathrm{P}$ load of $13 \mathrm{t} \mathrm{P} \mathrm{yr}^{-1}$. These loadings result in estimated DIN concentrations of 20 and $5.3 \mu \mathrm{g} \mathrm{N}^{-1}$ for the inner and outer parts of the estuary, respectively (Table 4). Thus, $N$ limitation will occur during 2/3 of the time (May to October) in the inner part and for about $95 \%$ of the time in the outer part. The estimated DIP concentrations corresponding to a TP load of $13 \mathrm{tyr}^{-1}$ to the estuary are 6.0 and $6.2 \mu \mathrm{g} \mathrm{Pl}^{-1}$ for the inner and outer parts, respectively, which are close to the values resulting in nutrient limitation for $2 / 3$ of the time from March to July. Please note that the concentrations for DIN (20 and $5.3 \mu \mathrm{g} \mathrm{N}^{-1}$ ) and DIP (6.0 and $\left.6.2 \mu \mathrm{g} \mathrm{P}^{-1}\right)$ are mean values over the season. Thus, higher concentrations, allowing nutrient-replete growth of phytoplankton, will still occur for approximately $1 / 3$ of the time.

The considerations above only take DIN and DIP into account despite the fact that dissolved organic matter is by far the largest pool of nutrients, e.g. the ratio of TN:DIN is about 150 (Figs. 4 and 6a). However, dissolved organic nitrogen (DON) is not readily taken up by phytoplankton, and is mainly used indirectly after mineralization of DON by bacteria. The concentrations of both inorganic and organic $\mathrm{N}$ and $\mathrm{P}$ are determinated by loadings, biological processes and mixing with the marine end member. On an annual scale the estuary is a reactor transforming DIN (approximately 80\% of the loadings) to DON (Stedmon et al., 2006; Markager et al., 2011).

An alternative method for defining the target values for good ecological status is to use the empirical models to calculate concentrations for TN and TP with the values for background loadings. These will theoretically give the TN and TP concentrations at pristine conditions. However, the empirical models are then used for scenarios with loads far outside the range used for setting up the models and the outcome is therefore uncertain. For TN the estimated pristine concentration is $398 \mu \mathrm{g}^{-1}$, when using the politically defined practice of accepting a $26 \%$ deviation from pristine conditions (Table 4). The corresponding load would be $743 \mathrm{t} \mathrm{N} \mathrm{yr}^{-1}$, or $33 \%$ higher than the above mentioned $560 \mathrm{t} \mathrm{N} \mathrm{yr}^{-1}$; however, given the uncertainty the two values are in reasonable agreement. For TP the model shows a low sensitivity between loadings and concentrations, and estimated pristine concentrations are so high than an addition of $26 \%$ will bring them above the present concentrations, which clearly do not support a good ecological status. Thus, this approach does not work for TP. The reason for the low sensitivity of the empirical model with respect to TP is probably a high amount of stored phosphorus in the sediments.

\subsection{Calculated groundwater and stream threshold values and groundwater chemical status in the catchment of Horsens estuary}

The maximum acceptable $\mathrm{N}$ and $\mathrm{P}$ loads (560 and $13 \mathrm{t}$ ) required to ensure a good ecological status of the Horsens estuary were estimated in the previous section. These loads correspond to 52 and $56 \%$ of the annual average TN and TP loads to the estuary for the period 2000 to 2005 , respectively. To meet these reduction targets, we calculate the following threshold values in the two possible scenarios described previously. 


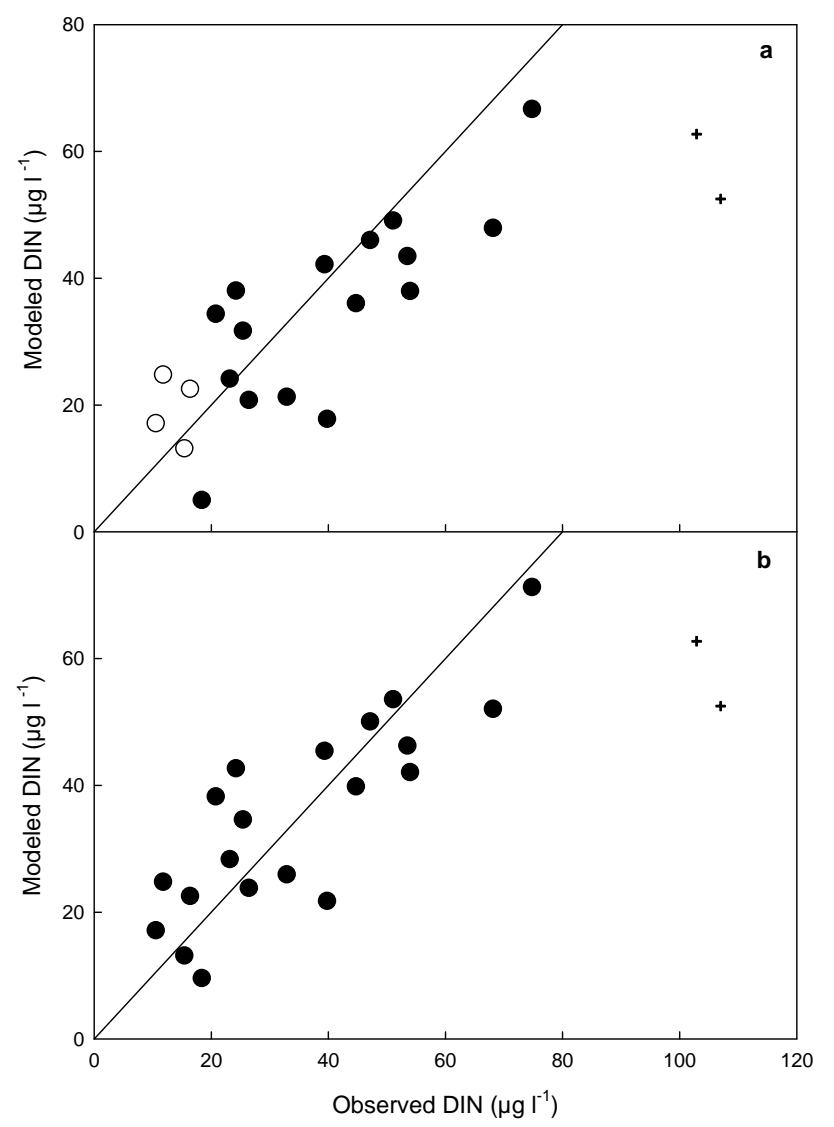

Fig. 7. (a) Observed and modeled values for inorganic nitrogen (DIN), average values from May to October from 1985 to 2006. Filled circles are values from 1985 to 2002, used in parameter selection. Open circles are values from 2003 to 2006, omitted and used for validation. + values from 1993 and 1994 are identified as outliers. (b) As (a), but all values from 1985 to 1992 and 1995 to 2006 are used for estimation of coefficients. Model: DIN (MayOctober, normalized $)=0.5570 \cdot \mathrm{N}$ load $($ January-October, normalized) $+0.52 \cdot$ Wind $^{3}$ (January the year before-October, normalized); $R^{2}=0.7$.

\subsubsection{Reduction targets and threshold values - scenario 1}

The first scenario assumes that all reduction targets for $\mathrm{N}$ and $\mathrm{P}$ are directed against the diffuse sources in the catchment (Table 7). The resulting TN and TP concentrations in inlet freshwater to the estuary are calculated at 2.9 and $0.084 \mathrm{mg}^{-1}$, respectively. The corresponding groundwater threshold value for TN in aerobic groundwater in the catchment is calculated at $6.0 \mathrm{mg} \mathrm{l}^{-1}$. No groundwater threshold value in the catchment can be calculated for $\mathrm{P}$ as diffuse sources such as soil erosion and stream bank erosion are important transport pathways which currently are not completely quantified.
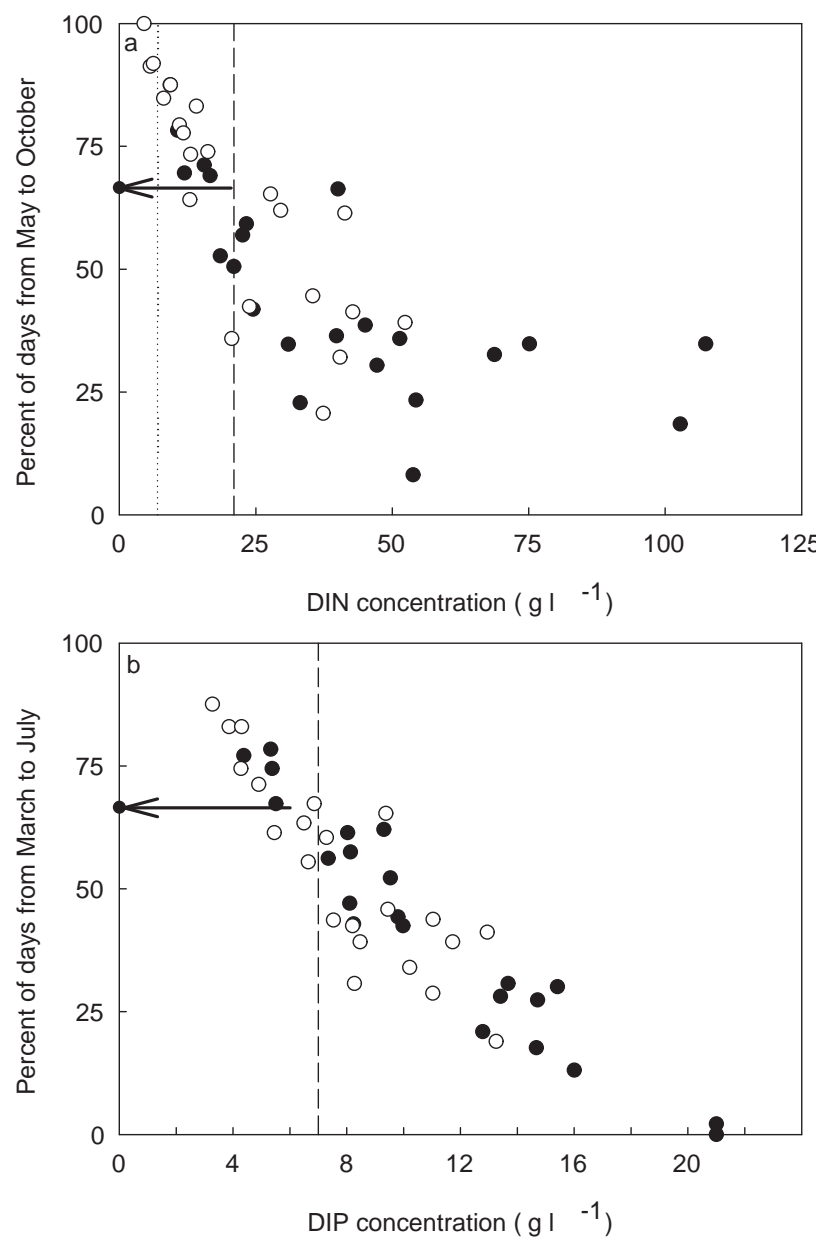

Fig. 8. (a) Relationship between mean concentration and percent of days with limitation for inorganic nitrogen, DIN, and (b) inorganic phosphorous, DIP. Calculated annually from 1985 to 2006 for Horsens estuary; filled circles (inner part), open circles (outer part), respectively. For DIN the calculations are performed on data from May to October (184 days), and limitation is assumed to occur when DIN $<14 \mu \mathrm{gl}^{-1}$. For DIP the period is from March to July (153 days), and limitation is assumed to occur when DIP $<6.2 \mu \mathrm{g} 1^{-1}$. The vertical dashed lines indicate when limitations occur for $2 / 3$ of the time, and the corresponding concentrations (DIN $21 \mu \mathrm{g} 1^{-1}$, DIP $7 \mu \mathrm{g} \mathrm{1^{-1 }}$ ) are considered the target values for good ecological status of the estuary. The vertical dotted line is the resulting DIN concentration for the outer part of the estuary with an annual $\mathrm{N}$ load of $560 \mathrm{t} \mathrm{yr}^{-1}$.

\subsubsection{Reduction targets and threshold values - scenario 2}

In the second scenario we are imposing reduction targets on point sources, direct atmospheric deposition (emission from agriculture of ammonia), and diffuse sources (Table 8). The resulting $\mathrm{N}$ concentration in inlet freshwater to the estuary is $3.1 \mathrm{mg} \mathrm{l}^{-1}$, and the corresponding groundwater threshold value of $\mathrm{N}$ is calculated at $9.3 \mathrm{mg} \mathrm{l}^{-1}$, thus being 
Table 7. Scenario for reductions in TN and TP in Horsens estuary where mitigation measures are only directed at diffuse sources in the catchment. The required reduction is in $\mathrm{t}$, the concentrations are in $\mathrm{mg}^{-1}$.

\begin{tabular}{lll}
\hline & \multicolumn{2}{c}{ Scenario 1 } \\
\cline { 2 - 3 } & $\mathrm{TN}$ & $\mathrm{TP}$ \\
\hline Reduction in diffuse sources & 526 & 10.4 \\
Current stream concentration & 6.2 & 0.15 \\
Stream threshold concentration & 2.9 & 0.084 \\
Current groundwater concentration & $15^{\mathrm{a}} / 0.3^{\mathrm{b}}$ & $0.018^{\mathrm{a}} / 0.13^{\mathrm{b}}$ \\
Groundwater threshold concentration & 6.0 & - \\
\hline
\end{tabular}

${ }^{\mathrm{a}}$ Aerobic groundwater; ${ }^{\mathrm{b}}$ anaerobic groundwater.

considerably higher than in scenario 1 . The reason is that reduction in point sources, direct loads, and targeted mitigation measures such as restored wetlands and uncultivated buffer zones will assist in reducing the loadings to the estuary. The scenario 2 calculations for $\mathrm{P}$ show that the reduction target for the estuary can be achieved in a longer term perspective by introducing targeted mitigation measures.

The calculated stream and groundwater threshold values for the two scenarios are compared to current TN and TP concentrations in Table 9. Note that the nitrate-N concentrations in streams is about $89 \%$ of the TN concentration based on measurements at monitoring stations; hence, the threshold value (TV) for nitrate-N is also $89 \%$ of the TV for TN given here. The TV for nitrate- $\mathrm{N}$ in groundwater equals in practice the TV for TN, based on measurements in monitoring wells. The modeled groundwater concentrations are recharge-weighted. The mean concentration of a sufficient number of monitoring wells in aerobic groundwater should equal this number if aerobic groundwater represents the same recharge period as the modeled baseline period, i.e. 2000 to 2005.

\section{Discussion}

\subsection{Estimate of TN and TP loads from gauged and un- gauged catchments to the Horsens estuary}

The model simulations of nitrogen leaching and the modeled gross and net nutrient emissions are believed to be of relatively high precision as the models applied are empirical models developed based on the national monitoring data from agricultural fields in agricultural catchments (Grant et al., 2007) and stream monitoring data from 80 catchments (Windolf et al., 2011). This conclusion is corroborated by the good fit to the measured stream concentrations in the gauged sub-catchments (Table 2). The simulated nitrogen concentrations in the Hansted catchment equal the measured values, whereas the simulated values in the Bygholm catchments are slightly lower than the measured values. The latter deviation is the cause of the slightly lower estimate for the annual $\mathrm{N}$ loading to the estuary based on simulated values for the Bygholm and Hansted catchments (1001 $\mathrm{t}$ for the period 2001 to 2005) as compared to the estimate using measured $\mathrm{N}$ loadings for these two catchments $(1086 \mathrm{t})$. Of course, this will also affect the final computed threshold values for TN (Table 9). A previous inter-comparison of model estimates has shown that the precision of $\mathrm{N}$ modeling in catchments is rather high, whereas $\mathrm{P}$ modeling estimates currently have a poor precision (Kronvang et al., 2009b). It is worth noticing that the simulated $\mathrm{N}$ concentrations, fluxes and retention in the investigated catchment are comparable to what has been found in previous Danish studies in a coastal catchment of the Odense estuary about $50 \mathrm{~km}$ southeast of the Horsens catchment. This catchment has a comparable setting and a data record of nearly $50 \mathrm{yr}$ (e.g. Hinsby et al., 2008; Larsen et al., 2008).

\subsection{Estimate of maximum acceptable loads}

A key issue for management of an estuary is to establish maximum acceptable loads. An assessment of this involves the definition of target values for one or several parameters in the estuary that describe good ecological status. Then, models for quantitative relationships between loads and these parameters are needed to estimate the maximum acceptable loads required to reach these target values.

Recent research has demonstrated that dual-nutrient (N, P) reduction strategies are needed to alleviate eutrophication in estuaries and other coastal waters in the land-sea continuum (Boynton and Kemp, 2008; Conley et al., 2009; Paerl, 2009), and that the Redfield ratio for $\mathrm{N}$ and $\mathrm{P}$ in marine waters (16: 1, molar) cannot be considered a universally optimal ratio between $\mathrm{N}$ and $\mathrm{P}$, but rather an average of species-specific $\mathrm{N}$ : P ratios (Klausmeier et al., 2004; Ptacnik et al., 2010).

Our approach has been to define good ecological status as average concentrations of inorganic nutrients, which ensure nutrient limited phytoplankton growth in $2 / 3$ of the growth season, taking into account the natural seasonal cycle where phosphorous is limiting in the spring and nitrogen is limiting later in the growth season.

The choice of $2 / 3$ of the growth season may be debatable. Moreover, it is known that the $\mathrm{K}_{\mathrm{m}}$ value for growth of phytoplankton varies between species (e.g. Falkowski, 1975) and that growth rates are more closely coupled to the internal cell concentrations than to external concentrations. However, we still find that the selected approach is based on reasonable ecological rationales and that it gives a good indication of the nutrient concentration levels that ensure an acceptable ecological status of the estuary. As recognized by Duarte et al. (2009), the definition of target loads and concentrations for achieving good ecological status of estuaries is probably the most challenging part of the restoration process. In the end the definition of good ecological status will always have a political dimension, and our scientifically based definitions 
Table 8. Scenario for reductions in TN and TP in Horsens estuary. Reduction targets are in t, concentrations are in $\mathrm{mg} \mathrm{l}^{-1}$. Mitigation measures are directed both at point sources and atmospheric deposition from agriculture, and targeted as well as general mitigation measures against diffuse sources are also utilized.

\begin{tabular}{|c|c|c|}
\hline & \multicolumn{2}{|c|}{ Scenario 2} \\
\hline & $\mathrm{TN}$ & $\mathrm{TP}$ \\
\hline Total reduction target Horsens estuary & 526 & 10.4 \\
\hline \multicolumn{3}{|l|}{ Reduction in point sources } \\
\hline Closing of marine fish farm & 11 & 1.39 \\
\hline $50 \%$ reduction larger point sources & 40 & 2.75 \\
\hline Total & 51 & 4.14 \\
\hline \multicolumn{3}{|l|}{ Reduction in atmospheric deposition } \\
\hline $25 \%$ reduction atm. deposition & 25 & - \\
\hline Remaining reduction target Horsens estuary & 450 & 5.90 \\
\hline \multicolumn{3}{|l|}{ Targeted mitigation measures in catchment } \\
\hline Restored riparian wetlands (300 ha) & $60^{\mathrm{a}}$ & $3.0^{\mathrm{a}}$ \\
\hline $10 \mathrm{~m}$ buffer zones with tree planting along $300 \mathrm{~km}$ watercourses ${ }^{2}$ & $24^{\mathrm{a}}$ & $3.0^{\mathrm{b}}$ \\
\hline $\begin{array}{l}\text { Remaining reduction implemented as general mitigation } \\
\text { measures on diffuse sources }\end{array}$ & 366 & 0 \\
\hline Stream threshold concentration & 3.1 & 0.084 \\
\hline Groundwater threshold concentration & 9.3 & - \\
\hline
\end{tabular}

of good ecological status and implied targets for loadings can only be guidelines for the political decision process.

The use of empirical models for relationships between loads and nutrient concentrations in the estuary works well. However, it is important to remember that empirical models describe the present conditions in the estuary and only have a time lag between loads and effects in the estuary of approximately one year. Thus, effects with a longer time lag and possible regime shifts (Scheffer et al., 2001) are not accounted for. This is presumably the reason why changes in water clarity and depth limits of eelgrass give very weak models with low sensitivity (data not shown). This is most likely due to pools of nutrients stored in the sediments, which only slowly (presumably over decades) are released and emptied during a phase with decreasing loadings. Predicting these time lags and regime shifts, e.g. from the present phytoplankton dominated system back to an eelgrass dominated system, is extremely difficult but clearly a major scientific challenge for the coming years.

In conclusion, the empirical models applied here provide a reasonably good prediction of nutrient concentrations during changes in loadings within the range of loadings for which they are developed. Effects of changes in loadings significantly outside this range or for other regimes of the ecosystem are very uncertain. The lowest loadings in the data set encompass the predicted targets for $\mathrm{N}$ and $\mathrm{P}$, so the model is not used outside the data range. However, additional effects of processes with time lag of decades are not accounted for.
Table 9. Current groundwater and stream concentrations and calculated threshold values (TV) for TN and TP. The TVs are computed for the two scenarios (management options) described in the text. All values are in $\mathrm{mg} \mathrm{l}^{-1}$.

\begin{tabular}{lllll}
\hline & & $\begin{array}{l}\text { Current } \\
\text { conc. }\end{array}$ & $\begin{array}{l}\text { TV } \\
\text { Scenario 1 }\end{array}$ & $\begin{array}{l}\text { TV } \\
\text { Scenario 2 }\end{array}$ \\
\hline Groundwater & TN & $15^{\mathrm{a}}$ & $6.0^{\mathrm{a}}$ & $9.3^{\mathrm{a}}$ \\
(aerobic part) & TP & $0.018^{\mathrm{b}}$ & $-?^{\mathrm{c}}$ & $-?^{\mathrm{c}}$ \\
\hline Streams & TN & $6.1^{\mathrm{d}}$ & 2.9 & 3.1 \\
& TP & 0.15 & 0.084 & 0.084 \\
\hline
\end{tabular}

a Based on the combined use of monitoring and modeling data for the period 2000-2005; ${ }^{\mathrm{b}}$ based on monitoring data only; ${ }^{\mathrm{c}}$ estimation still not possible more research is needed; ${ }^{\mathrm{d}}$ average of modeled concentrations in the three sub-catchments of Horsens estuary.

\subsection{Scenarios and management options for $N$ and $P$ in Horsens estuary}

The reduction targets for $\mathrm{N}(526 \mathrm{t})$ and $\mathrm{P}(10.4 \mathrm{t})$ can be accomplished by different mitigation measures in the catchment and introducing improved treatment of sewage water at point sources discharging either to freshwater or directly to the estuary. As described previously, we have developed two possible management options that could be introduced to reduce the $\mathrm{N}$ and $\mathrm{P}$ loadings to levels allowing good ecological status in the Horsens estuary. 
The first scenario assumes that the entire $\mathrm{N}$ reduction is obtained by introducing mitigation measures, which reduce the $\mathrm{N}$ leaching from the root zone of agricultural fields. The inlet $\mathrm{TN}$ and TP concentrations in freshwater discharging to the Horsens estuary has to be reduced from 6.2 to $2.9 \mathrm{mg} \mathrm{l}^{-1}$ and $0.15 \mathrm{mg} \mathrm{l}^{-1}$ to $0.084 \mathrm{mg} \mathrm{l}^{-1}$, respectively, for obtaining good ecological status. The resulting model calculated threshold value of $\mathrm{TN}$ in the root zone and aerobic groundwater at and below a depth of one meter is $6.0 \mathrm{mg} \mathrm{l}^{-1}$ (equivalent to $26.5 \mathrm{mg} \mathrm{l}^{-1} \mathrm{NO}_{3}^{-}$) as an average for the entire catchment area (Table 7). However, the threshold value for $\mathrm{TN}$ under agricultural fields can be allowed to be higher $\left(7.4 \mathrm{mg}^{-1}\right.$, equivalent to $32.7 \mathrm{mg} \mathrm{l}^{-1} \mathrm{NO}_{3}^{-}$) because approximately one third of the catchment area is in a non-agricultural land cover category, with a low background concentrations of TN in groundwater ( $<1 \mathrm{mg} \mathrm{l}^{-1}$ in some areas, Postma et al., 1991) and streams (approximately $1.2 \mathrm{mgl}^{-1}$ ) (Kronvang et al., 2005). As phosphorus is derived via many hydrological pathways (leaching, erosion, and surface runoff) to surface waters (Kronvang et al., 2007), it is not possible to calculate a groundwater $\mathrm{P}$ threshold value with our current knowledge.

Our second reduction scenario for $\mathrm{N}$ and $\mathrm{P}$ involves reduction in discharges of nutrients from point sources, enhancing $\mathrm{N}$ and $\mathrm{P}$ retention processes in surface waters (reestablishing riparian wetlands, introducing buffer strips, etc.), and reductions in diffuse sources (Hejzlar et al., 2006; Hoffmann et al., 2009, 2011; Kronvang et al., 2009a). Such a catchment management plan allows the groundwater threshold value to be higher (average for entire catchment area is $9.3 \mathrm{mg} \mathrm{N}^{-1}$ ) than in the first scenario. The threshold $\mathrm{N}$ concentration under agricultural fields in the catchment is then calculated to $11.8 \mathrm{mg} \mathrm{N}^{-1}$ (52 $\mathrm{mgl}^{-1}$ as nitrate). Note that the latter is above the US as well as the European drinking water standards of $10 \mathrm{mg}^{-1}$ nitrate-N ( $\sim 4 \mathrm{mgl}^{-1}$ nitrate) and $50 \mathrm{mg}^{-1}$ nitrate, respectively. In such a case the drinking water standard will have to be applied as a threshold value according to European directives and guidelines. The second scenario for $\mathrm{P}$ seems to be enough to reduce the $\mathrm{P}$ loadings to the required target and reach the corresponding threshold value of $0.084 \mathrm{mg} \mathrm{l}^{-1}$ for phosphorus in streams. This will, however, take some time as some of the surface water management methods need a long period to work efficiently in reducing $\mathrm{P}$ (buffer strips, Table 7).

An additional management option for reduction of nutrient loadings to the estuary is linked to a spatial analysis of nitrogen sources within the catchment of Horsens estuary, where the catchment is divided into sub-catchments (Windolf et al., 2011). Lumped results of model calculations of gross $\mathrm{N}$ emissions and sinks within 27 sub-catchments are available for the Horsens estuary catchment. Eight of these sub-catchments are located downstream of the larger lakes in the catchment (downstream from the two river monitoring stations), so management of $\mathrm{N}$ within agricultural production in this area will be most cost effective as no natural $\mathrm{N}$ reduction takes place in lakes in these sub-catchments (Thodsen et al., 2009).

The management option chosen is to transform land use from agricultural land to forest land in this $154 \mathrm{~km}^{2}$ subcatchment. This will lead to a reduction of the $\mathrm{N}$ loading to the estuary of $200 \mathrm{tN}$ per year. The remaining $326 \mathrm{tN}$ has to be removed from the catchment upstream the two larger lakes. An annual $\mathrm{N}$ retention of $13 \%$ of the incoming $\mathrm{N}$ load to the two lakes (Bygholm and Nørrestrand) has been calculated using the $\mathrm{N}$ retention model from Windolf et al. (2011). Thus, the $\mathrm{N}$ loading to these two lakes has to be reduced to $409 \mathrm{t} \mathrm{N}$ per year. As the retention of $\mathrm{N}$ in groundwater and surface waters within the catchment upstream the two lakes amounts to around $60 \%$ of the $\mathrm{N}$ leached from the root zone, we can calculate that the threshold $\mathrm{N}$ concentration in upper groundwater can be allowed to be approximately $10 \%$ higher than the threshold value of $7.4 \mathrm{mg} \mathrm{N}^{-1}$ under agricultural areas calculated in scenario 1 .

\subsection{Estimation of groundwater threshold values from maximum acceptable loads and different management options}

It has been demonstrated through the previous sections that groundwater threshold values derived based on maximum acceptable loads to an associated aquatic ecosystem depend on technically and politically realistic management options to reduce nutrient loads to the ecosystem. Consequently, groundwater threshold values for nutrients derived to protect ecosystems will never be universal as drinking water standards typically are. Ecological driven groundwater threshold values should always be derived for a specific geological, climatological and agricultural setting. Values derived for similar settings may, however, be used if data on given water bodies and ecosystems are insufficient for derivation of groundwater threshold values. Groundwater threshold values derived for a comparable setting should probably often be preferred to drinking water standards, which are currently used as the threshold value for nitrate by most European countries. The calculated groundwater thresholds in this paper are average annual flow (recharge)-weighted concentrations acceptable in aerobic groundwater discharging to streams in the catchment. As the water table and the upper aerobic groundwater zone are very shallow in the investigated catchment $(<5 \mathrm{~m})$, the aerobic groundwater generally recharged the aquifers within the last few years. Hence, average concentrations in a representative number of monitoring screens in the aerobic zone (if present) should not exceed the flow-weighted groundwater threshold values obtained by the conducted model simulations. Unfortunately, the number of monitoring wells in aerobic groundwater in the catchment is very small and several of them are probably screened across the redox boundary. The average $\mathrm{TN}$ concentration in aerobic groundwater calculated from monitoring wells in the aerobic 


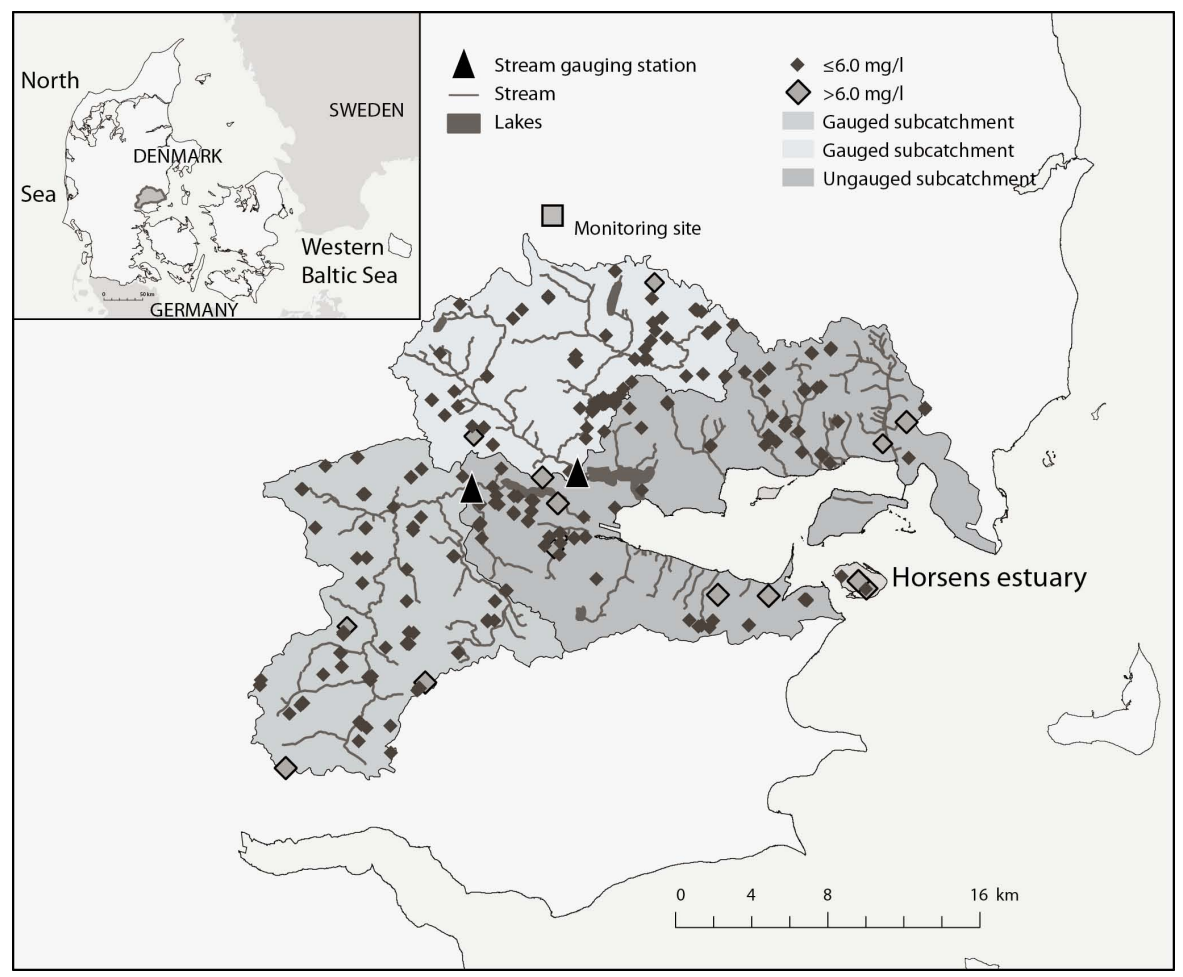

Fig. 9. Nitrate-N concentrations $\left(\mathrm{mg}^{-1}\right)$ in groundwater monitoring wells (latest measurement). Most monitoring wells are located in anaerobic groundwater and therefore contain no nitrate and low dissolved inorganic nitrogen concentrations (DIN).

zone is therefore not considered to be representative for aerobic groundwater in the catchment.

\subsection{Groundwater chemical status}

If a groundwater threshold value derived for protection of an associated ecosystem is breached in a given groundwater body, the groundwater body or part of a groundwater body has to be classified as having poor status. In the case of nitrogen, for example, it is necessary to evaluate the concentrations of the different nitrogen species separately for the aerobic and anaerobic parts of the groundwater bodies. This is important as nitrate, which represents practically the entire $\mathrm{TN}$ in aerobic groundwater, is reduced to the inactive, harmless $\mathrm{N}_{2}$ in anaerobic groundwater (e.g. Appelo and Postma, 2005). Consequently, TN concentrations are typically more than an order of magnitude lower in the anaerobic zone than in the aerobic zone, and the anaerobic zone thus contributes relatively little to $\mathrm{N}$ loads.

Hence, the general groundwater chemical status in the catchment based on nitrogen species should generally be assessed for the aerobic groundwater separately. Conceptual models of the extension of the aerobic groundwater and their role for surface water nitrogen loads as represented here (Fig. 2) should support the risk analysis. If data on aerobic groundwater are missing or scarce, measured stream nitrate or TN concentrations are useful indicators of the status of the shallow aerobic groundwater in the catchment, when wastewater and other nitrogen sources are taken into account. This is clearly illustrated when comparing results from Fig. 9 and Table 9. Figure 9 leaves the impression that relatively few groundwater bodies have problems with nitrate, while data in Table 9 clearly demonstrate that nitrate concentrations are generally too high in the catchment. Hence, the conducted model simulations show that the groundwater chemical status based on nitrate concentrations in aerobic groundwater is generally poor below farm lands in the area, and that the quality of shallow aerobic groundwater in the catchment does not comply with European legislation.

\subsection{Implications for integrated monitoring and modeling of water bodies}

The previous section clearly demonstrates that groundwater and surface water monitoring should be integrated in order to obtain as much information as possible on the chemical status of both water body types, and in order to derive meaningful groundwater threshold values for protection of associated and dependent aquatic and terrestrial ecosystems. As the ecological status of surface waters depends on the nutrient loadings and the seasonality in nutrient loadings, water quality monitoring programs should provide the necessary data to calculate and simulate these by coupled groundwater and surface water models, not least when possible climate change impacts have to be assessed (Andersen et al., 2006; Sonnenborg et al., 2012). In addition, reliable models and design of 
efficient monitoring programs for assessment of groundwater impacts on ecosystems require a sound understanding of the site specific hydrogeological, physical, and chemical conditions controlling the groundwater-surface water interaction (Dahl et al., 2007; Dahl and Hinsby, 2012). This challenges the traditional and still very relevant groundwater monitoring of major aquifers, which is targeted at drinking water interests. Furthermore, it may also challenge surface water monitoring traditions, as models being able to simulate runoff and nutrient concentrations with a high spatial and temporal variation and coverage are needed, and they require reliable monitoring data for calibration.

\subsection{Climate change impact on $\mathbf{N}$ and $P$ loadings to coastal ecosystems}

Before concluding this work a short note on the possible effect of projected climate change on groundwater threshold values in the investigated study area is called for. Much research is currently undertaken in order to assess the projected climate change impact on the hydrological cycle globally. Previous work has indicated that winter precipitation and hence nutrient loadings to coastal waters may increase in Denmark, which is located in the western Baltic Sea (Andersen et al., 2006; Jeppesen et al., 2009, 2011; Aquarius, 2011; Sonnenborg et al., 2012), and in the Baltic Sea in general (Hagg et al., 2010), although significant uncertainties exist, e.g. due to changes in crops and farming practices (Olesen et al., 2007). Furthermore, while increased temperatures are expected to increase crop yields in the North Sea and Baltic Sea regions (Aquarius, 2011), the increased temperatures will render coastal ecosystems more prone to harmful algal blooms (Paerl and Huisman, 2009) and hypoxia as mineralization accelerates with higher temperatures. In such a scenario groundwater threshold values will have to be lower than the values derived in this paper. Hence, for Denmark and the other countries in the region the mitigation measures, which are implemented to assure good chemical and ecological status of water bodies, may not be sufficient in the future, as projected climate change may work against these. The present paper sets the scene and establishes the needed knowledge base for an integrated understanding of the Horsens estuary and catchment system for the assessment of climate change impacts on groundwater threshold values and chemical status in the future. The approach presented in this paper is applicable in many coastal catchments, globally.

\section{Conclusions}

As a result of the intensive agriculture in Denmark, the majority of Danish coastal waters have poor ecological status. Hence, the development of catchment or river basin management plans for reduction of nutrient loads and determination of threshold values in groundwater, streams, and estuaries are becoming increasingly important. The present study analyses and presents (1) the historical and current nutrient loadings for the investigated Horsens estuary, (2) the current ecological conditions of the estuary, and (3) necessary reductions in nutrient loadings for obtaining a good ecological status in the estuary applying a combination of empirical loadingresponse models. We estimate that the TN and TP annual loads for the investigated baseline period (2000 to 2005) should be reduced to 560 and $13 \mathrm{t}$, respectively, corresponding to 52 and $56 \%$ of the annual average for the investigated baseline period. Using different scenarios we demonstrate that especially the groundwater threshold values and maximum acceptable concentrations are quite sensitive to the choice of mitigation measures and management options in the catchment. Depending on the selected management scenario, we estimate that groundwater threshold values for TN vary between 6.0 and $9.3 \mathrm{mg} \mathrm{l}^{-1}$, while the corresponding stream threshold values vary between 2.9 and $3.1 \mathrm{mgl}^{-1}$. As the current modeled average concentrations in shallow aerobic groundwater and streams are 15 and $6.2 \mathrm{mgl}^{-1}$, respectively, our investigation clearly shows that groundwater and stream threshold values are breached in the catchment. Hence, the major part of the shallow aerobic groundwater in the catchment of Horsens estuary is of poor chemical status due to farming practices and does not comply with the European Water Framework and Groundwater Directives. To obtain good chemical status for shallow aerobic groundwater in the investigated catchment, our data show that the average TN concentration should be lowered to approximately half (40 to $62 \%$ - depending on the applied management option) of the present concentration. These reductions correspond to $\mathrm{NO}_{3}-\mathrm{N}$ threshold values in the range of $6-9 \mathrm{mg}^{-1}$ (or 27 to $41 \mathrm{mg}^{-1}$ of nitrate), assuming that the nitrate species constitute the entire $\mathrm{TN}$ in shallow aerobic groundwater. According to our evaluation, the flow-weighted annual average concentration of TP in streams in the catchment should be lowered from the present 0.15 to $0.084 \mathrm{mg} \mathrm{l}^{-1}$. However, the present study indicates that it is not relevant to establish groundwater threshold values for TP in the investigated catchment as the elevated concentrations apparently occur only in anaerobic groundwater due to dissolution from natural sources, and a major and unknown part of the TP in streams originates from brink erosion. The transport of TP is, however, not as well understood as the transport of TN and should be investigated further. It is interesting to note that one of the presented management scenarios would allow aerobic groundwater nitrate concentrations below farm lands even above drinking water standards if focusing solely on the good status objective for the estuary. However, such high concentrations would jeopardize the chemical status of groundwater used for drinking water, and the ecological status of ecosystems in the catchment such as lakes and wetlands. Hence, an integrated assessment of acceptable loads and thresholds for both coastal waters and surface and subsurface waters in the catchment is imperative when thresholds have to cover other relevant 
ecosystems in a catchment such as lakes and protected terrestrial ecosystems. The threshold values derived in this study to ensure good ecological status of the Horsens estuary may not ensure good ecological status for all ecosystems in the catchment. Furthermore, climate change impacts will most probably require lower groundwater and stream threshold values in the future to ensure good ecological status of associated aquatic ecosystems.

\section{Appendix A}

\section{Calculation of precision and bias on TN loadings in streams}

The mean precision (Root Mean Square Error, RMSE) and bias from the validation of the model for TN loading at the two gauged stream stations are calculated to amount to $15.2 \%$ and $10.5 \%$, respectively. Combining the uncertainty of the TN loading from both gauged (precision: $10 \%$; bias: $0 \%$; mean $\mathrm{N}$ loading: $726 \mathrm{t} \mathrm{N} \mathrm{yr}^{-1}$ ) and ungauged catchment areas (mean TN loading: $570 \mathrm{t} \mathrm{N} \mathrm{yr}^{-1}$ ) of the Horsens estuary reveals a mean precision and bias, shown in Eqs. (A1) and (A2), respectively.

Precision of TN loading :

$$
\frac{\sqrt{ }(726 \times 0.1+570 \times 0.152)^{2}}{(726+570)} \times 100 \%=8.7 \% \text {. }
$$

Bias on TN loading :

$$
\frac{(726 \times 0+570 \times 0.105)}{726+570} \times 100 \%=4.6 \% \text {. }
$$

The precision (RMSE) and bias calculated for the TN loading can be considered an estimate of the precision and bias of the TN loading estimates for the model scenarios.

Acknowledgements. This article is an outcome of the EU Interreg IVB project CLIWAT. It has been co-funded by the North Sea Region Program 2007-2013 under the ERDF of the European Union, and supported by the Danish Strategic Research Foundation projects MONITECH (104-08-0050) and MAFIA (09-067259). We acknowledge Lauren Paige Seaby for linguistic assistance, and Dirk-Ingmar Müller-Wohlfeil for his constructive review, which improved the manuscript.

Edited by: A. Guadagnini

\section{References}

Abbott, M., Bathurst, J., Cunge, J., Oconnell, P., and Rasmussen, J.: An Introduction to the European Hydrological System - Systeme Hydrologique Europeen, She. 2. Structure of a Physically-Based, Distributed Modeling System, J. Hydrol., 87, 61-77, 1986.

Andersen, H. E., Kronvang, B., and Larsen, S. E.: Development, validation and application of Danish empirical phosphorus models, J. Hydrol., 304, 355-365, 2005.

Andersen, H. E., Kronvang, B., Larsen, S. E., Hoffmann, C. C., Jensen, T. S., and Rasmussen, E. K.: Climate-change impacts on hydrology and nutrients in a Danish lowland river basin, Sci. Total Environ., 365, 223-237, 2006.

Appelo, C. A. J. and Postma, D.: Geochemistry, groundwater and pollution, Balkema, Leiden, 2005.

Aquarius: Main findings from Aquarius - Farmers as water managers in the North Sea region, Report from the Aquarius project, the Interreg IVB North Sea Region Programme, Knowledge Centre for Agriculture, Aarhus, 2011.

BLST: Vandplan - Hovedopland 1.9 Horsens, Danish Agency for Spatial and Environmental Planning, Ministry of the Environment, Copenhagen, 1-206, 2010.

Boynton, W. R. and Kemp, W. M.: Estuaries, in: Nitrogen in the Marine Environment, edited by: Capone, D. G., Bronk, D. A., Mulholland, M. R., and Carpenter, E. J., Elsevier, Burlington, 809-866, 2008.

Broadhurst, D., Goodacre, R., Jones, A., Rowland, J. J., and Kell, D. B.: Genetic algorithms as a method for variable selection in multiple linear regression and partial least squares regression, with applications to pyrolysis mass spectrometry, Anal. Chim. Acta, 348, 71-86, 1997.

Camargo, J. A. and Alonso, A.: Ecological and toxicological effects of inorganic nitrogen pollution in aquatic ecosystems: A global assessment, Environ. Int., 32, 831-849, 2006.

Christensen, P. B., Rysgaard, S., Sloth, N. P., Dalsgaard, T., and Schwærter, S.: Sediment mineralization, nutrient fluxes, denitrification and dissimilatory nitrate reduction to ammonium in an estuarine fjord with sea cage trout farms, Aquat. Microb. Ecol., 21, 73-84, 2000.

Cloern, J.: Our evolving conceptual model of the coastal eutrophication problem, Mar. Ecol.-Prog. Ser., 210, 223-253, 2001.

Conley, D. J., Kaas, H., Mohlenberg, F., Rasmussen, B., and Windolf, J.: Characteristics of Danish estuaries, Estuaries, 23, 820837, 2000.

Conley, D. J., Markager, S., Andersen, J., Ellermann, T., and Svendsen, L. M.: Coastal eutrophication and the Danish National Aquatic Monitoring and Assessment Program, Estuaries, 25, 848-861, 2002.

Conley, D. J., Paerl, H. W., Howarth, R. W., Boesch, D. F., Seitzinger, S. P., Havens, K. E., Lancelot, C., and Likens, G. E.: Controlling Eutrophication: Nitrogen and Phosporus, Science, 323, 114-115, 2009.

Dahl, M. and Hinsby, K.: Typology of groundwater - surface water interaction (GSI typology), in: Groundwater and Ecosystems, Selected papers on Hydrogeology 17, edited by: Ribeiro, L., Stigter, T. Y., Chambel, A., Condesso de Melo, M. T., Monteiro, J. P., and Medeiros, A., Taylor and Francis, Oxon, in press, 2012.

Dahl, M., Nilsson, B., Langhoff, J. H., and Refsgaard, J. C.: Review of classification systems and new multi-scale typology of groundwater-surface water interaction, J. Hydrol., 344, 1-16, 
2007.

Diaz, R. J. and Rosenberg, R.: Spreading dead zones and consequences for marine ecosystems, Science, 321, 926-929, 2008.

Duarte, C. M., Conley, D. J., Carstensen, J., and Sánchez-Camacho, M.: Return to Neverland: Shifting baselines affect eutrophication restoration targets, Estuar. Coast., 32, 29-36, 2009.

Eppley, R. W., Rogers, J. N., and McCarthy, J. J.: Half-saturation constants for uptake of nitrate and ammonium by marine phytoplankton, Limnol. Oceanogr., 14, 912-920, 1969.

EU, directive 2000/70/EC: The EU Water Framework Directive, 2000.

EU, directive 2006/118/EC: The EU Groundwater Directive, 2006.

EU, directive 2009/90/EC: The Monitoring Directive, 2009.

Falkowski, P. G.: Nitrate uptake in marine phytoplankton: Comparison of half saturation constants from seven species, Limnol. Oceanogr., 20, 412-417, 1975.

Galloway, J. N., Dentener, F. J., Capone, D. G., Boyer, E. W., Howarth, R. W., Seitzinger, S. P., Asner, G. P., Cleveland, C. C., Green, P. A., Holland, E. A., Karl, D. M., Michaels, A. F., Porter, J. H., Townsend, A. R. and Vorosmarty, C. J.: Nitrogen cycles: past, present, and future, Biogeochemistry, 70, 153-226, 2004.

Gustafsson, K. E. and Bendtsen, J.: Elucidating the dynamics and mixing agents of a shallow fjord through age tracer modeling, Estuar. Coast. Shelf S., 74, 703-716, 2007.

Graham, D. N. and Butts, M. B.: Flexible, integrated watershed modelling with MIKE SHE, in: Watershed models, edited by: Singh, V. P. and Frevert, D. K., CRC Press, Boca Raton, FL., 245-272, 2005.

Grant, R., Blicher-Mathiesen, G., Pedersen, L. E., Jensen, P. G., Madsen, I., Hansen, B., Brüsch, W., and Thorling, L.: Landovervågningsoplande 2006, National Environmental Research Institute, Aarhus University, Aarhus, 123 pp., 2007.

Griebler, C., Stein, H., Kellermann, C., Berkhoff, S., Brielmann, H., Schmidt, S., Selesi, D., Steube, C., Fuchs, A., and Hahn, H. J.: Ecological assessment of groundwater ecosystems - Vision or illusion?, Ecol. Eng., 36, 1174-1190, 2010.

Hagg, H. E., Humborg, C., Morth, C. M., Medina, M. R., and Wulff, F.: Scenario Analysis on Protein Consumption and Climate Change Effects on Riverine N Export to the Baltic Sea, Environ. Sci. Technol., 44, 2379-2385, 2010.

Hansen, B., Thorling, L., Dalgaard, T., and Erlandsen, M.: Trend Reversal of Nitrate in Danish Groundwater - a Reflection of Agricultural Practices and Nitrogen Surpluses since 1950, Environ. Sci. Technol., 45, 228-234, 2011.

Hejzlar, J., Samalova, K., Boers, P., and Kronvang, K.: Modeling phosphorus retention in lakes and reservoirs, Water Air Soil Poll., 6, 487-494, 2006.

Hejzlar, J., Anthony, S., Arheimer, B., Behrendt, H., Bouraoui, F., Grizzetti, B., Groenendijk, P., Jeuken, M. H. J. L., Johnsson, H., Lo Porto, A., Kronvang, B., Panagopoulos, Y., Siderius, C., Silgram, M., Venohr, M. and Zaloudik, J.: Nitrogen and phosphorus retention in surface waters: an inter-comparison of predictions by catchment models of different complexity, J. Environ Monitor., 11, 584-593, 2009.

HELCOM: HELCOM Baltic Sea Action Plan, HEE, 101 pp., 2007.

Henriksen, H. J., Troldborg, L., Nyegaard, P., Sonnenborg, T. O., Refsgaard, J. C., and and Madsen, B.: Methodology for construction, calibration and validation of a national hydrological model for Denmark, J. Hydrol., 280, 52-71, 2003.
Hinsby, K. and Jørgensen, L. F.: Groundwater monitoring in Denmark and the Odense Pilot River Basin in relation to EU legislation, in: Groundwater Monitoring, Ph. Quevauviller, AM Fouillac, edited by: Grath, J. and Ward, R., Wiley, Hoboken, 207-224, 2009.

Hinsby, K., de Melo, M. T. C., and Dahl, M.: European case studies supporting the derivation of natural background levels and groundwater threshold values for the protection of dependent ecosystems and human health, Sci. Total Environ., 401, 1-20, 2008.

Hoffmann, C. C., Kjaergaard, C., Uusi-Kamppa, J., Hansen, H. C. B., and Kronvang, B.: Phosphorus Retention in Riparian Buffers: Review of Their Efficiency RID B-6714-2011, J. Environ. Qual., 38, 1942-1955, 2009.

Hoffmann, C. C., Kronvang, B., and Audet, J.: Evaluation of nutrient retention in four restored Danish riparian wetlands, Hydrobiologia, 674, 5-24, 2011.

Jeppesen, E., Kronvang, B., Meerhoff, M., Sondergaard, M., Hansen, K. M., Andersen, H. E., Lauridsen, T. L., Liboriussen, L., Beklioglu, M., Ozen, A., and Olesen, J. E.: Climate Change Effects on Runoff, Catchment Phosphorus Loading and Lake Ecological State, and Potential Adaptations, J. Environ. Qual., 38, 1930-1941, 2009.

Jeppesen, E., Kronvang, B., Olesen, J. E., Audet, J., Sondergaard, M., Hoffmann, C. C., Andersen, H. E., Lauridsen, T. L., Liboriussen, L., Larsen, S. E., Beklioglu, M., Meerhoff, M., Ozen, A., and Ozkan, K.: Climate change effects on nitrogen loading from cultivated catchments in Europe: implications for nitrogen retention, ecological state of lakes and adaptation, Hydrobiologia, 663, 1-21, 2011.

Klausmeier, C., Litchman, E., Daufresne, T., and Levin, S.: Optimal nitrogen-to-phosphorus stoichiometry of phytoplankton, Nature, 429, 171-174, 2004.

Kronvang, B. and Bruhn, J. A.: Choice of sampling strategy and estimation method when calculating nitrogen and phosphorus transport in small lowland streams, Hydrol. Process., 10, 14831501, 1996.

Kronvang, B., Grant, R., Larsen, S. E., Svendsen, L. M., and Kristensen, P.: Non-Point-Source Nutrient Losses to the Aquatic Environment in Denmark - Impact of Agriculture, Marine Freshwater Res., 46, 167-177, 1995.

Kronvang, B., Jeppesen, E., Conley, D. J., Sondergaard, M., Larsen, S. E., Ovesen, N. B., and Carstensen, J.: Nutrient pressures and ecological responses to nutrient loading reductions in Danish streams, lakes and coastal waters, J. Hydrol., 304, 274-288, 2005.

Kronvang, B., Vagstad, N., Behrendt, H., Bogestrand, J., and Larsen, S. E.: Phosphorus losses at the catchment scale within Europe: an overview, Soil Use Manage., 23, 104-116, 2007.

Kronvang, B., Andersen, H. E., Borgesen, C., Dalgaard, T., Larsen, S. E., Bogestrand, J., and Blicher-Mathiasen, G.: Effects of policy measures implemented in Denmark on nitrogen pollution of the aquatic environment, Environ. Sci. Policy, 11, 144-152, 2008.

Kronvang, B., Hoffmann, C. C., and Dröge, R.: Sediment deposition and net phosphorus retention in a hydraulically restored lowland river-floodplain in Denmark: combining field studies with laboratory experiments, Marine Freshwater Res., 60, 638-646, 2009a. 
Kronvang, B., Behrendt, H., Andersen, H. E., Arheimer, B., Barr, A., Borgvang, S. A., Bouraoui, F., Granlund, K., Grizzetti, B., Groenendijk, P., Schwaiger, E., Hejzlar, J., Hoffmann, L., Johnsson, H., Panagopoulos, Y., Lo Porto, A., Reisser, H., Schoumans, O., Anthony, S., Silgram, M., Venohr, M. and Larsen, S. E.: Ensemble modelling of nutrient loads and nutrient load partitioning in 17 European catchments, J. Environ. Monitor., 11, 572-583, 2009b.

Kristensen, K., Waagepetersen, J., Børgesen, C. D., Vinther, F. P., Grant, R., and Blicher-Mathiesen, G.: Reestimation and further development in the model N-LES N-LES3 to N-LES4, DJ F PLANT SCIENCE, 139, Faculty of Agricultural Sciences, Aarhus University, Denmark, 2008.

Larsen, M. A. D., Soegaard, H., and Hinsby, K.: Temporal trends in $\mathrm{N} \& \mathrm{P}$ concentrations and loads in relation to anthropogenic effects and discharge in Odense River 1964-2002, Hydrol. Res., 39, 41-54, 2008.

Larsen, S. E., Kronvang, B., Windolf, J., and Svendson, L. M.: Trends in diffuse nutrient concentrations and loading in Denmark: Statistical trend analysis of stream monitoring data, Water Sci. Technol., 39, 197-205, 1999.

Lomstein, B. A., Jensen, A.-G. U., Hansen, J. W., Andreasen, J. B., Hansen, L. S., Berntsen, J., and Kunzendorf, H.: Budgets of sediment nitrogen and carbon cycling in the shallow water of Knebel Vig, Denmark, Aquatic Microbial Ecology, Vol. 14, 6980, 1998.

MacIsaac, J. J. and Dugdale, C.: The kinetics of nitrate and ammonia uptake by natural populations of marine phytoplankton, Deep-Sea Res., 16, 45-57, 1969.

Markager, S., Bassompierre, M., and Petersen, D. J.: Analyse af Miljøtilstanden i Horsens Fjord fra 1985 til 2006 - empirisk modellering, Nationals University, Aarhus, 1-90, 2010.

Markager, S., Stedmon, C. A., and Sondergaard, M.: Seasonal dynamics and conservative mixing of dissolved organic matter in the temperate eutrophic estuary Horsens Fjord, Estuar. Coast. Shelf S., 92, 376-388, 2011.

Martens, H. A. and Dardenne, P.: Validation and verification of regression in small data sets, Chemometr. Intell. Lab., 44, 99-121, 1998.

Olesen, J. E., Carter, T. R., az-Ambrona, C. H., Fronzek, S., Heidmann, T., Hickler, T., Holt, T., Minguez, M. I., Morales, P., Palutikof, J. P., Quemada, M., Ruiz-Ramos, M., Rubaek, G. H., Sau, F., Smith, B., and Sykes, M. T.: Uncertainties in projected impacts of climate change on European agriculture and terrestrial ecosystems based on scenarios from regional climate models, Climatic Change, 81, 123-143, 2007.

Paerl, H. W.: Controlling Eutrophication along the Freshwater Marine Continuum: Dual nutrient (N and $\mathrm{P}$ ) Reductions are Essential, Estuar. Coast., 32, 593-601, 2009.

Paerl, H. W. and Huisman, J.: Climate change: a catalyst for global expansion of harmful cyanobacterial blooms, Environmental Microbiology Reports, 1, 27-37, 2009.

Postma, D., Boesen, C., Kristiansen, H., and Larsen, F.: Nitrate reduction in an unconfined sandy aquifer - water chemistry, reduction processes and geochemical modeling, Water Resour. Res., 27, 2027-2045, 1991.
Ptacnik, R., Andersen, T., and Tamminen, T.: Performance of the Redfield Ratio and a Family of Nutrient Limitation Indicators as Thresholds for Phytoplankton N vs. P Limitation, Ecosystems, 13, 1201-1214, 2010.

Quile, K., Becker, A., Kirchesch, V., Schöl, A., and Fisher, H.: Influence of global change on phytoplankton and nutrient cycling in the Elba River, Reg. Environ. Change, 11, 405-442, 2011.

Rockstrom, J., Steffen, W., Noone, K., Persson, A., Chapin, F. S., Lambin, E. F., Lenton, T. M., Scheffer, M., Folke, C., Schellnhuber, H. J., Nykvist, B., de Wit, C. A., Hughes, T., van der Leeuw, S., Rodhe, H., Sorlin, S., Snyder, P. K., Costanza, R., Svedin, U., Falkenmark, M., Karlberg, L., Corell, R. W., Fabry, V. J., Hansen, J., Walker, B., Liverman, D., Richardson, K., Crutzen, P., and Foley, J. A.: A safe operating space for humanity, Nature, 461, 472-475, 2009.

Scheffer, M., Straile, D., van Nes, E. H., and Hosper, H.: Climatic warming causes regime shifts in lake food webs, Limnol. Oceanogr., 46, 1780-1783, 2001.

Sonnenborg, T. O., Hinsby, K., van Roosmalen, L., and Stisen, S.: Assessment of climate change impacts on the quantity and quality of a coastal catchment using a coupled groundwater-surface water model, Climatic Change, 113, 10251048, doi:10.1007/s10584-011-0367-3, 2012.

Stedmon, C. A., Markager, S., Sondergaard, M., Vang, T., Laubel, A., Borch, N. H., and Windelin, A.: Dissolved organic matter (DOM) export to a temperate estuary: Seasonal variations and implications of land use, Estuar. Coast., 29, 388-400, 2006.

Thodsen, H., Kronvang, B., Andersen, H. E., Larsen, S. E., Windolf, J., Jørgensen, T. B., and Troldborg, L.: Modeling diffuse nitrogen loadings of ungauged and unmonitored lakes in Denmark: application of an integrated modeling framework, International Journal of River Basin Management, 7, 245-257, 2009.

Tilman, D., Fargione, J., Wolff, B., D’Antonio, C., Dobson, A., Howarth, R., Schindler, D., Schlesinger, W. H., Simberloff, D., and Swackhamer, D.: Forecasting agriculturally driven global environmental change, Science, 292, 281-284, 2001.

Timmermann, K., Markager, S., and Gustafsson, K. E.: Streams or open sea? Tracing sources and effects of nutrient loadings in a shallow estuary with a 3D hydrodynamic-ecological model, J. Marine Syst., 82, 111-121, 2010.

Vitousek, P. M., Aber, J. D., Howarth, R. W., Likens, G. E., Matson, P. A., Schindler, D. W., Schlesinger, W. H., and Tilman, G. D.: Human alteration of the global nitrogen cycle: Sources and consequences, Ecol. Appl., 7, 737-750, 1997.

Windolf, J., Jeppesen, E., Jensen, J. P., and Kristensen, P.: Modelling of seasonal variation in nitrogen retention and in-lake concentration: A four-year mass balance study in 16 shallow Danish lakes, Biogeochemistry, 33, 25-44, 1996.

Windolf, J., Thodsen, H., Troldborg, L., Larsen, S. E., Bogestrand, J., Ovesen, N. B., and Kronvang, B.: A distributed modelling system for simulation of monthly runoff and nitrogen sources, loads and sinks for ungauged catchments in Denmark, J. Environ. Monitor., 13, 2645-2658, 2011. 